Rubia Rodrigues

\title{
Estudo de um modelo experimental para o desenvolvimento de enfisema pulmonar induzido por elastase e fumo em camundongos
}

Dissertação apresentada à Faculdade de Medicina da Universidade de São Paulo para obtenção do título de Mestre em Ciências

Programa de Fisiopatologia Experimental Orientadora: Profa Dra. Fernanda Degobbi Tenorio Quirino dos Santos Lopes 
Rubia Rodrigues

\section{Estudo de um modelo experimental para o desenvolvimento de enfisema pulmonar induzido por elastase e fumo em camundongos}

Dissertação apresentada à Faculdade de Medicina da Universidade de São Paulo para obtenção do título de Mestre em Ciências

Programa Fisiopatologia Experimental Orientadora: Profa Dra. Fernanda Degobbi Tenorio Quirino dos Santos Lopes 


\section{Dados Internacionais de Catalogação na Publicação (CIP)}

Preparada pela Biblioteca da

Faculdade de Medicina da Universidade de São Paulo

Creprodução autorizada pelo autor

\section{Rodrigues, Rubia}

Estudo de um modelo experimental para o desenvolvimento de enfisema pulmonar induzido por elastase e fumo em camundongos / Rubia Rodrigues. -São Paulo, 2015

Dissertação(mestrado)--Faculdade de Medicina da Universidade de São Paulo. Programa de Fisiopatologia Experimental.

Orientadora: Fernanda Degobbi Tenorio Quirino dos Santos Lopes.

Descritores: 1.Modelos animais 2.Doença pulmonar obstrutiva crônica 3.Elastase pancreática 4.Tabaco 5.Líquido da lavagem broncoalveolar 6.Macrófagos 7.Metaloproteinase 12 da matriz 8.NADPH oxidase.

USP/FM/DBD-152/15 
À minha família, razão de toda luta e de eu ser quem sou. 


\section{Agradecimentos}

À Professora Fernanda Degob6i Tenorio Quirino dos Santos Lopes, minha orientadora, a quem devo agradecer por toda compreensão, paciência e motivação. Pela amizade e por ter me dado as mãos com carinho maternal em muitos momentos difíceís.

À Juliana Dias Lourenço (Julis) e Aline Riane, por me ajudarem nas exposições, pela amizade e por se dedicarem a esse trabalho como se fosse de vocês.

À Juliana Tiyaki Ito e Daniela $\mathcal{A}$. Brito Cervilha, que chegaram, como anjos, no momento em que mais precisava de ajuda. Não tenho palavras para agradecer!

$\mathcal{A}$ Clarice Rosa Olivo, pelos "toques" sempre perspicazes e as vezes duros, pela amizade e por ser tão leonina!

À Francine Maria de Almeida, por toda competência, ajuda e carinho. Te admiro muito!

À minha querída amiga-irmã Petra de Mello Motta Arantes (Pedrita), que me trouxe até o $\mathcal{L} I \mathcal{M} 20$ e com quem dividi muitos bons e maus momentos. Obrigada amiga por estar ao meu lado, pelas estadias, pelas dicas e sugestões e principalmente por sua amizade!

À Fabiola Robertoni (Fabi), pelo carinho e pelas boas conversas com direito a discussões politicas que nos fazem crescer sempre.

Aos amigos e colegas do $\mathcal{L} I \mathcal{M} 20$ com quem convivi nesse periodo, especialmente:

Davi Simões Sales pelo carinho, sotaque gostoso e alegría que contagia.

Davi Francísco Ferreira, funcionário dedicado e atencioso que está sempre pronto a nos ajudar no que precisarmos.

Rosana Aparecida, secretáría do LIM 20, sempre solícita e pronta a ajudar. 
Dra. Iolanda Calvo Tíbério, por ter sido tão gentíl comigo e por ter me encaminhado ao tratamento contra a depressão.

Aos meus amigos de profissão, por me ajudarem no desafio diário do ensinar tornando um pouco menos cansativa a jornada de trabalho, pelos momentos de luta pelas ruas de São Paulo e por serem exemplos de dedicação e perseverança. $\mathcal{A}$ vocês dedico esse trabalho com a esperança de que um dia professores e professoras sejam verdadeiramente respeitados nesse pais!

À minha amiga linda Priscila de Oliveira (Pri), pela amizade verdadeira, por me ouvir e me apoiar sempre que precisei, pelos conselhos, pela boa energía e alegría contagiantes. Axé neguinha!

丸̀ minha amiga Sara Hamaguchi (Sarinha), muitas vezes meu anjo da guarda, por estar sempre comigo em vários momentos difíceis da minha vida. Sua amizade é muito valiosa pra mim!

À $\mathcal{E l z a}$ (Elzinha), pela amizade, carinho, conforto e calma que sempre me recebe e me ouví. Você é exemplo de força e superação para mim!

Aos meus país, pelo exemplo que são em minha vída. Minha mãe, apesar de não estar maís nesse plano, é exemplo de amor e dedicação e meu pai pelo otimismo, caráter e honestidade com que vive a vida. Nõa tería chegado até aqui sem vocês!

Ao meu fítho Diego, que me faz mais forte a cada dia, o grande motivo pelo qual eu iníciei a pós graduação. Quero que tenha orgutho de mim!

Ao meu companheiro Rodolfo, pelo apoío e compreensão e por ter me mostrado o amor como nunca havia experimentado. 
"Clesmo quando tudo parece desabar, cabe a mim decidir entre vir ou chorar, ir ou ficar, desistir ou lutar, porque descobri, no caminho incerto da vida, que o mais impontante é o decidir." Pora Poralina 


\section{SUMÁRIO}

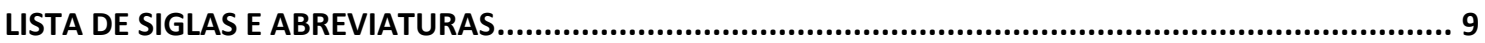

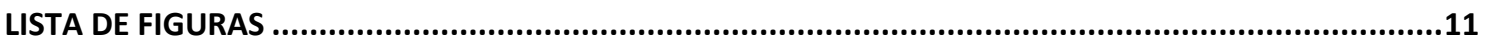

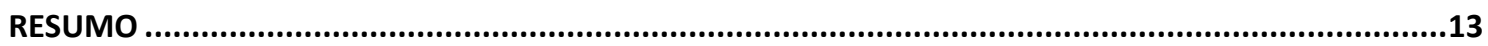

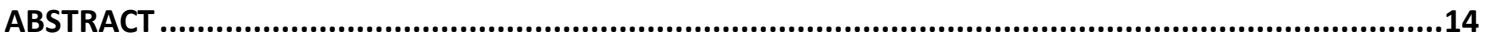

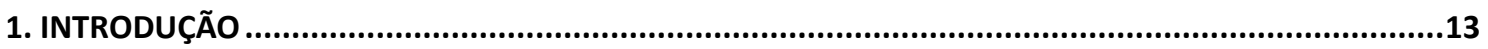

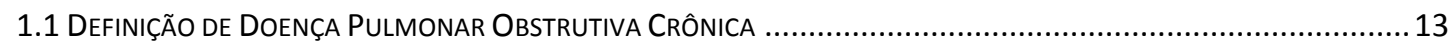

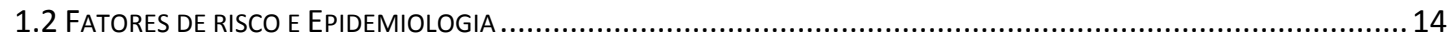

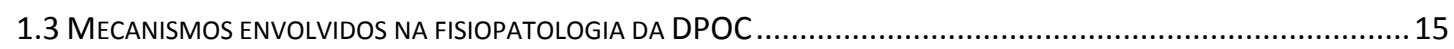

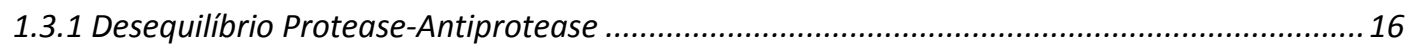

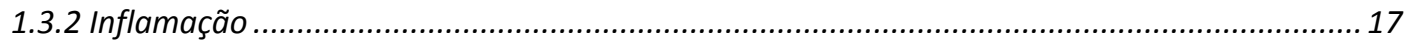

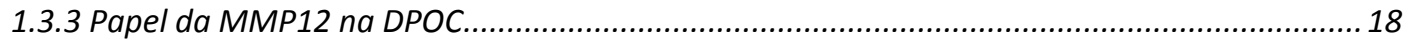

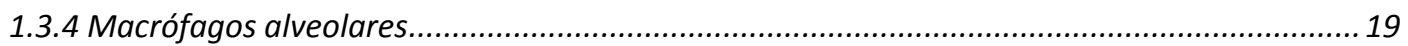

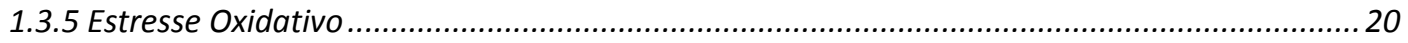

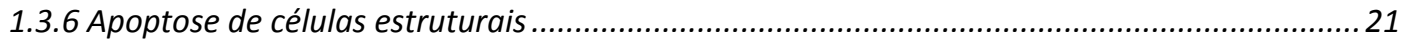

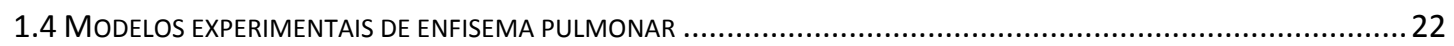

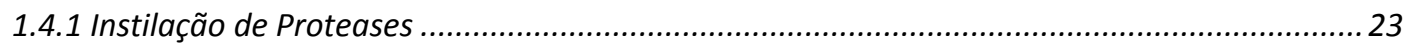

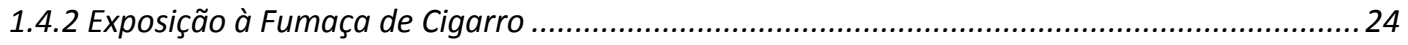

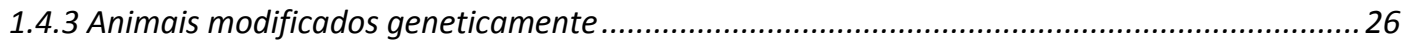

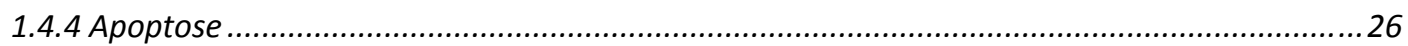

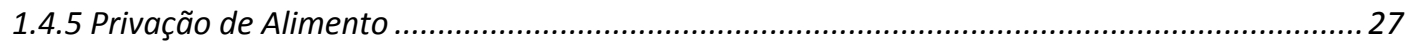

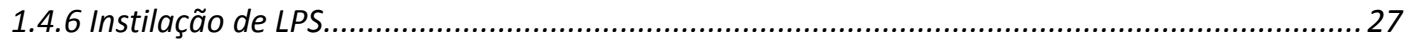

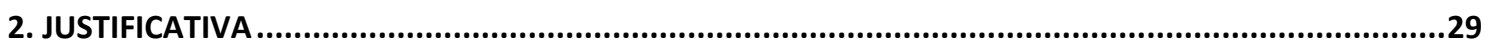

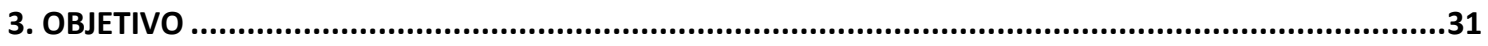

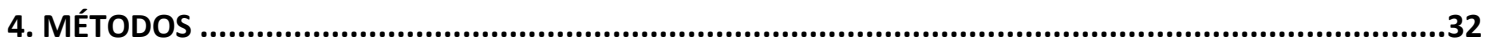

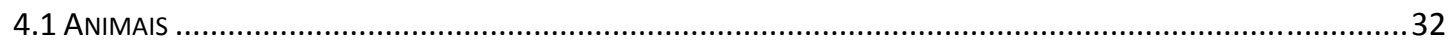




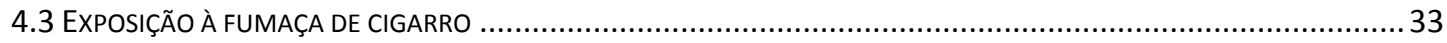

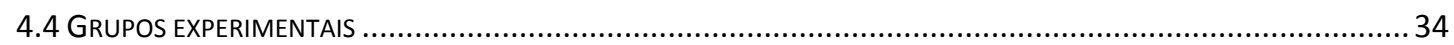

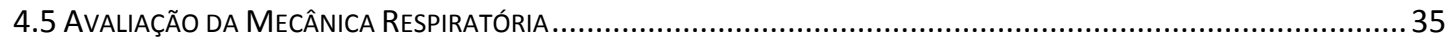

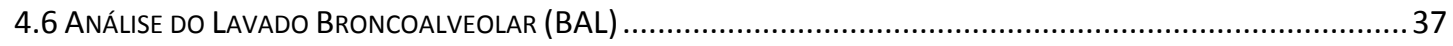

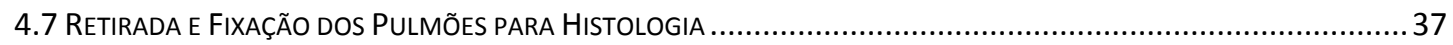

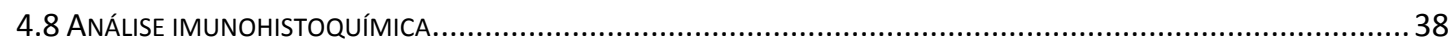

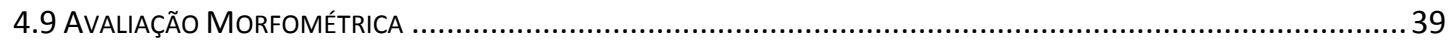

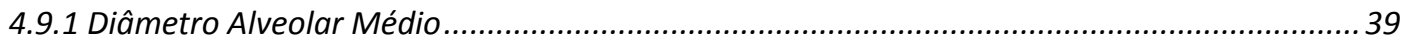

4.9.2 Contagem de Macrófagos (MAC2) e Células Positivas para MMP-12, Caspase 3 e GP91.......40

4.10 ANÁLISE ESTATÍSTICA

5. RESULTADOS

5.1 MECÂNICA RESPIRATÓRIA

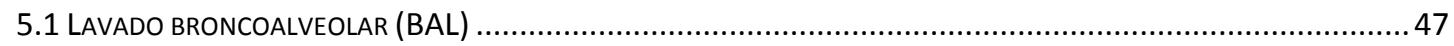

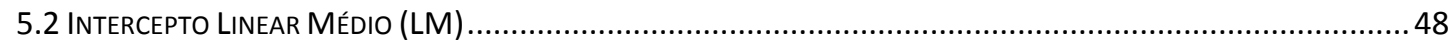

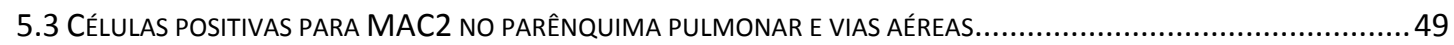

5.4 CÉLULAS POSITIVAS PARA MMP12 NO PARÊNQUIMA PULMONAR E VIAS AÉREAS ..........................................50

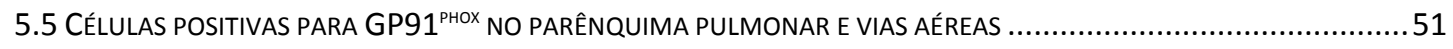

5.6 CÉlULAS POSITIVAS PARA CASPASE 3 NO PARÊNQUIMA PULMONAR E VIAS AÉREAS.......................................5

5.7 PROPORÇÃO DE FIBRAS DE COLÁGENO NO PARÊNQUIMA PULMONAR .......................................................5

5.8 PROPORÇÃO DE FIBRAS ELÁSTICAS NO PARÊNQUIMA PULMONAR .........................................................5

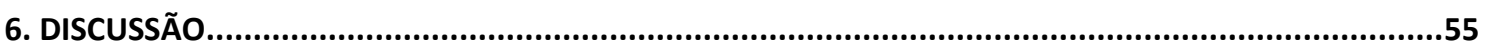

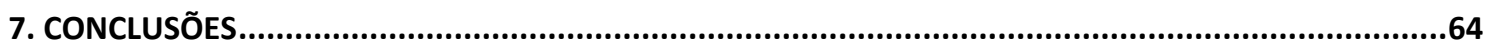

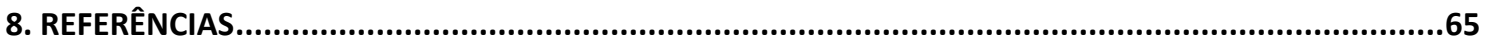




\section{LISTA DE SIGLAS E ABREVIATURAS}

$\begin{array}{ll}\text { ANVISA } & \text { Agência Nacional de Vigilância Sanitária } \\ \text { OMS } & \text { Organização Mundial de Saúde } \\ \text { EP } & \text { Erro Padrão } \\ \text { a1-AT } & \text { a1-antitripsina }\end{array}$

BAL Lavado Bronco Alveolar

BSA Bovine Serum Albumin

CONAMA Conselho Nacional do Meio Ambiente

DPOC Doença Pulmonar Obstrutiva Crônica

DNA Ácido Desoxirribonucleico

GOLD Global Initiative for Chronic Obstructive Lung Disease

Gtis Resistência tecidual

GP91 ${ }^{\text {phox }} \quad$ Proteína glicosilada do fagócito

Htis Elastância tecidual

LM Intercepto linear médio

LPS Lipopolissacarideo

LTB4 Leucotrieno B4

Raw Resistência de vias aéreas

MAC Macrófago

MMP-12 Metaloprotease de matrix

NADPH Nicotinamida Adenina Dinucleotídeo Fosfato Oxirredutase

$\mathrm{NO}_{2} \quad$ Dióxido de Nitrogênio

VEG Fator de Crescimento Endotelial

ERO Espécie Reativa de Oxigênio

$\mathbf{c m H}_{2} \mathrm{O} \quad$ Centímetros de Água

UI Unidade Internacional

IL-8 Interleucina 8 
mg

ml

$\mathrm{Kg}$

$\mu \mathrm{m}$

$\mathrm{mm}$

$\min$

PPE

RPM

SF

TNF- $\alpha$

Zrs

V

V'

VEF1
Miligramas

Mililitros

Kilogramas

Micrômetro

Milimetros

Minutos

Elastase Pancreática de Porco

Rotação por minutos

Solução Fisiológica

Fator de Necrose Tumoral

Impedância do sistema respiratório

Volume

Fluxo

Volume Expiratório Forçado após 1 segundo 


\section{LISTA DE FIGURAS}

Figura 1: Esquema ilustrativo da caixa de exposição à fumaça de cigarro (adaptado de Biselli, 2011)

Figura 2: Esquema do respirador para pequenos animais (Flexivent-Scireq) 36

Figura 3: Fotomicrografia do retículo sobre uma lâmina (Coloração em HE e aumento de 200X)

Figura 4: Fotomicrografia do retículo sobre uma lâmina, com as células positivas marcadas em marrom (aumento de 400X)

Figura 5: Resistência de vias aéreas (Raw) dos 5 grupos experimentais. Não houve diferença estatisticamente significativa entre os grupos, $p=0,358$. Os valores estão expressos como média \pm EP. (Controle $n=9$, Elastase $n=9$, Fumo $n=10$, Fumo/Elastase 1 dose $n=10$, Fumo/Elastase 2 doses) 45

Figura 6: Resistência do tecidopulmonar (Gtis) dos 5 grupos experimentais. Não houve diferença estatisticamente significativa entre os grupos, $p=0,059$. Os valores estão expressos como média \pm EP. (Controle $n=9$, Elastase $n=9$, Fumo $n=10$, Fumo/Elastase 1 dose $n=10$, Fumo/Elastase 2 doses) 45

Figura 7: Elastância do tecido pulmonar (Htis) dos 5 grupos experimentais. 46

Figura 8: $\mathrm{Na}$ análise do lavado bronco alveolar (BAL), 47

Figura 9: Valores do Intercepto Linear Médio (LM) nos 5 grupos 48

Figura 10: Contagem de macrófagos (MAC2) no parênquima pulmonar. Os valores estão expressos como média \pm EP. ${ }^{*} p<0,05$ comparado aos grupos Controle, Elastase e Fumo. 49

Figura 11: Contagem macrófagos (MAC2) nas vias aéreas. Os valores estão expressos como média \pm EP. ${ }^{*} p<0,05 e^{* *} p<0,05$ comparados ao Controle, Elastase e Fumo. 49

Figura 12: Contagem de células positivas para MMP12 no parênquima pulmonar. Os valores estão expressos como média \pm EP. ${ }^{*} p<0,05$ comparado ao grupo Controle. 50

Figura 13: Contagem de células positivas para MMP12 nas vias aéreas. Os valores estão expressos como média \pm EP. Apesar de o grupo Elastase apresentar um aumento 
aparente, ele não foi estatisticamente significativo, quando comparado aos outros grupos, $p=0,059$.

Figura 14: Contagem de células positivas para GP91 ${ }^{\text {phox }}$ no parênquima pulmonar. Os valores estão expressos como média \pm EP. Sendo ${ }^{*} p<0,05,{ }^{* *} p<0,05$, comparado aos grupos Controle e Elastase e \#p=0,028, comparado ao grupo Controle. 51

Figura 15: Contagem de células positivas para GP91 ${ }^{\text {phox }}$ nas vias aéreas. Os valores estão expressos como média \pm EP. Sendo ${ }^{*} p<0,05 e^{* *} p<0,05$, quando comparados aos grupos Controle e Elastase. Apesar de o grupo Fumo/Elastase 2 doses apresentar um aumento aparente em relação ao Controle ele não foi estatisticamente significativo.

Figura 16: Contagem de células positivas para Caspase 3 no parênquima pulmonar. Os valores estão expressos como média \pm EP. Não houve diferença estatisticamente significativa entre os grupos, $p=0,872$.

Figura 17: Contagem de células positivas para Caspase 3 nas vias aéreas. Os valores estão expressos como média \pm EP. Não houve diferença estatisticamente significativa entre os grupos, $p=0,472$. 52

Figura 18: Proporção de fibras de colágeno no parênquima pulmonar nos 53

Figura 19: Proporção de fibras elásticas no parênquima pulmonar remanescente dos 5 grupos experimentais. 54 


\section{RESUMO}

Rodrigues R. Estudo de um modelo experimental para o desenvolvimento de enfisema pulmonar induzido por elastase e fumo em camundongos [Dissertação]. São Paulo: Faculdade de Medicina, Universidade de São Paulo; 2015.

Os modelos experimentais têm sido utilizados para o estudo dos mecanismos fisiopatológicos envolvidos no desenvolvimento da Doença Pulmonar Obstrutiva Crônica (DPOC). O modelo que melhor mimetiza a doença em humanos é o que utiliza a exposição à fumaça de cigarro. No entanto, a utilização deste modelo experimental requer um longo tempo de exposição (6 meses) e a lesão do parênquima obtida é considerada leve. O desequilíbrio protease/anti-protease é considerado um importante mecanismo fisiopatológico envolvido no desenvolvimento da DPOC. Desta forma, neste estudo propomos o desenvolvimento de um modelo experimental no qual associamos a instilação de elastase previamente ao início da exposição ao fumo na tentativa de obter um maior grau de lesão tecidual em um menor espaço de tempo. Para tanto, camundongos C57BI/6 foram divididos em quatro grupos: Controle, Elastase, Fumo, Fumo/Elastase 1 dose e Fumo/Elastase 2 doses e analisados após dois meses de exposição. Os animais do grupo Fumo/Elastase 1 dose e 2 doses foram submetidos à instilação intranasal de elastase pancreática de porco $(0,33 \mathrm{UI})$ e expostos a fumaça de cigarro por dois meses. O grupo controle recebeu o mesmo tratamento com solução fisiológica ( $\mathrm{NaCl} 0.9 \%$ ). A exposição ao fumo foi feita por 30min, 2 vezes/dia, 5 dias da semana. Após dois meses, os animais foram sacrificados e observamos aumento de LM no grupo Fumo/Elastase 1 dose e 2 doses comparado aos grupos Controle e Fumo; aumento de células positivas para MAC-2 no parênquima (Fumo/Elastase 2 doses) e vias aéreas (Fumo/Elastase 1 dose e 2 doses), MMP-12 no parênquima pulmonar (Fumo/Elastase 2 doses), GP91 no parênquima (Fumo/Elastase 1 dose e 2 doses) e vias aéreas (Fumo e Fumo/Elastase 1 dose) e aumento de proporção de fibras elásticas no parênquima pulmonar do grupo Fumo/Elastase 1 dose e do grupo Fumo, caracterizando presença de enfisema pulmonar. A instilação de elastase pancreática de porco juntamente com a exposição à fumaça de cigarro aumentou a susceptibilidade ao desenvolvimento do enfisema.

Descritores: modelos animais; doença pulmonar obstrutiva crônica; elastase pancreática; tabaco; líquido da lavagem broncoalveolar; macrófagos; metaloproteinase 12 da matrix; NADPH oxidase. 


\section{ABSTRACT}

Rodrigues R. An experimental model of elastase and cigarette smoke-induced emphysema in mice [Dissertation]. São Paulo: "Faculdade de Medicina, Universidade de São Paulo"; 2015.

Experimental models have been used to study the pathophysiological mechanisms involved in the development of COPD. Cigarette Smoke exposure (CS) is considered the best model to mimetize the disease in humans. However, the CS requires a long exposure time (6 months) and the parenchymal destruction obtained is considered mild. The protease / anti protease imbalance is considered an important pathophysiological mechanism involved in the development of COPD. Thus, in this study we propose the development of an experimental model in which we associate instillation of elastase before the start of exposure to smoke, trying to increase the parenchymal destruction degree in a shorter time. For that, C57BL / 6 mice were divided into four groups: Control, Elastase, Smoke and Smoke/Elastase 1 dose and Smoke/Elastase 2 doses and analyzed in two months after the CS exposition. The Smoke/Elastase 1 dose and 2 doses animals group received an intranasal instillation of porcine pancreatic elastase $(0.33 \mathrm{IU})$ and exposed to cigarette smoke for two months. The control group received the same treatment with saline ( $\mathrm{NaCl} 0.9 \%$ ). Animals were exposed to CS for 30min, 2 times / day, 5 days a week. After two months, we observed increased mean linear intercept (LM) and positive cells for MAC-2, MMP-12 and GP91 in the airways and lung parenchyma and increase of elastic fibers in the lung parenchyma characterizing the presence of pulmonary emphysema. The instillation of porcine pancreatic elastase along the exposure to cigarette smoke increased susceptibility to the development of emphysema.

Descriptors: models, animal; pulmonary disease, chronic obstructive; pancreatic elastase; tobacco; bronchoalveolar lavage fluid; macrophages; matrix metalloproteinase 12; NADPH oxidase. 


\section{INTRODUÇÃO}

\subsection{Definição de Doença Pulmonar Obstrutiva Crônica}

A Doença Pulmonar Obstrutiva Crônica (DPOC) é a quarta principal causa de mortalidade no mundo e uma importante e crescente causa de morbidade crônica, gerando altos custos para a saúde pública, além de significativa incapacidade e redução da qualidade de vida (Churg et al., 2008; GOLD, 2013). É uma doença progressiva e incurável, porém prevenível e tratável, caracterizada por acometimento pulmonar com efeitos sistêmicos importantes, que podem contribuir de forma variável para sua gravidade. Os sintomas característicos da DPOC são dispnéia crônica e progressiva, tosse crônica e hipersecreção de muco (GOLD, 2013).

O componente pulmonar da DPOC é caracterizado por limitação crônica, normalmente progressiva, e associada a uma resposta inflamatória anormal dos pulmões a partículas ou gases nocivos (GOLD, 2013). A limitação ao fluxo aéreo é causada por comprometimento das pequenas vias aéreas (bronquiolite obstrutiva) e pela destruição do parênquima pulmonar (enfisema). No entanto, nem todos os portadores de DPOC seguem o mesmo curso na progressão da doença, apresentando alterações de graus variados (Churg et al., 2008; Halbert et al., 2006). Além disso, a DPOC tem efeitos extrapulmonares importantes que levam a comorbidades como perda de peso, anormalidades nutricionais e disfunção muscular esquelética (GOLD, 2013). 


\subsection{Fatores de risco e Epidemiologia}

O principal fator de risco para o desenvolvimento da DPOC é o tabagismo (Churg et al., 2008; Hecke et al., 2002). Entretanto, não são todos os tabagistas que desenvolvem DPOC clinicamente significativa, o que nos sugere haver outros fatores intrínsecos ao indivíduo envolvidos na sua patogênese (Churg et al., 2008). A DPOC também está relacionada a inalação de poluentes decorrentes da queima de combustíveis fósseis e à exposições inalatórias ocupacionais a poeiras e gases tóxicos (GOLD, 2013). No Brasil, a última estimativa de prevalência do tabagismo realizada em 2007 mostra que este atinge $16,4 \%$ na população de 18 a 100 anos, sendo $20,9 \%$ dos homens e $12,6 \%$ das mulheres (OMS, 2010).

A deficiência em a-1 antitripsina, um inibidor primário da elastase neutrofílica, é outro fator de risco importante para o desenvolvimento da DPOC, principalmente em indivíduos que apresentam o hábito de fumar. Piitulainen et al. (1999), demonstraram uma piora da função pulmonar, no período de 1 ano, em indivíduos que apresentavam deficiência em $\alpha-1$ antitripsina fumantes comparados aos ex-fumantes e aos indivíduos que nunca fumaram.

Há pouco mais de 40 anos, duas linhas de pesquisa, uma experimental e outra clínica, sugeriram que o enfisema era causado pela destruição das fibras elásticas pela enzima elastase. A primeira foi descrita por Laurell e Eriksson, em 1963, onde eles observaram que 3 dos 5 pacientes deficientes em a-1 antitripsina desenvolveram enfisema. A segunda foi em 1965, através de um experimento desenvolvido por Gross e colaboradores, que instilaram 
papaína nos pulmões de roedores e observaram o desenvolvimento desta doença.

Esses resultados foram primordiais para o início dos estudos em enfisema experimental através da instilação de proteases.

\subsection{Mecanismos envolvidos na fisiopatologia da DPOC}

As alterações fisiopatológicas características da DPOC, como inflamação crônica e alterações estruturais, são encontradas nas vias aéreas proximais e periféricas, parênquima e vasculatura pulmonar. A resposta inflamatória a fumaça do cigarro e outras partículas nocivas parece estar aumentada em quem desenvolve a DPOC, e não melhora mesmo após o abandono do hábito de fumar. A inflamação é ainda aumentada pelo estresse oxidativo e excesso de proteinases no pulmão (GOLD, 2013).

Essas alterações são decorrentes do processo de lesão e reparação constantes do tecido, levando a hipersecreção mucosa, disfunção ciliar, limitação ao fluxo aéreo, hiperinsuflação pulmonar, anomalias nas trocas gasosas, hipertensão pulmonar e cor pulmonale, que se desenvolvem geralmente nessa ordem durante o curso da doença. (GOLD, 2013).

Entre os mecanismos envolvidos no desenvolvimento e progressão do enfisema, incluem-se a hipótese protease-antiprotease, inflamação, estresse oxidativo e apoptose (Suki et al., 2003). 


\subsubsection{Desequilíbrio Protease-Antiprotease}

Ainda hoje, a hipótese mais aceita para explicar a destruição tecidual no enfisema é o desequilíbrio entre a atividade de proteases e anti-proteases. $O$ mecanismo proposto é de que células inflamatórias ativadas liberem proteases que destroem as fibras constituintes do parênquima pulmonar por se apresentarem em maior quantidade comparadas às anti-proteases, o que acarreta perda de elasticidade tecidual (Suki et al., 2003; Saetta et al., 2003). Normalmente essas enzimas proteolíticas são neutralizadas por antiproteases. Porém, em fumantes que desenvolvem DPOC, a produção de antiproteases pode ser insuficiente para neutralizar essas enzimas e evitar a lesão pulmonar (Barnes et al., 2003).

Diversas proteases estão aumentadas na DPOC, especialmente as metaloproteases de matriz - MMPs (MMP-1, MMP-8, MMP-12 e MMP-13) (GOLD, 2013). Há evidências crescentes de que macrófagos e neutrófilos de enfisematosos produzam MMPs, com atividades tanto colagenolítica quanto elastolítica, gerando peptídeos quimiotáticos que promovem recrutamento de mais macrófagos para o tecido. Em pacientes enfisematosos a MMP-1 (colagenase) e a MMP-9 (gelatinase B) estão em maior quantidade no lavado bronco alveolar (BAL). A MMP-9 também apresenta maior atividade no parênquima pulmonar desses pacientes, levando a maior atividade elastolítica no tecido (Barnes et al., 2003). 


\subsubsection{Inflamação}

Neutrófilos, macrófagos e linfócitos $T$ são as principais células inflamatórias envolvidas no padrão específico de inflamação da DPOC. Essas células liberam mediadores inflamatórios e interagem com células das vias aéreas e parênquima pulmonar (GOLD, 2013).

Em estudos feitos por Lacoste (1993) e Keatings (1996) foi observado aumento de neutrófilos ativados em amostras de escarro e no lavado broncoalveolar (BAL) de pacientes com DPOC. Estas células inflamatórias são responsáveis pela secreção de proteases, incluindo elastase neutrofílica, envolvida no aumento da produção de muco pelo epitélio das vias aéreas e na destruição das paredes alveolares. Fatores quimiotáticos incluindo interleucina 8 (IL-8) e leucotrieno B4 (LTB4) promovem a migração neutrofílica da circulação sistêmica para o trato respiratório. $\mathrm{O}$ aumento no número de neutrófilos nos brônquios e amostras de escarro está relacionado à gravidade da doença (Barnes et al., 2003).

É observado também um aumento do número de macrófagos em regiões de lesão do parênquima alveolar em enfisematosos, havendo também uma correlação entre o número destas células e a gravidade da doença. Quando ativados, os macrófagos liberam mediadores como o TNF- $\alpha$, a IL-8, LTB4 e espécies reativas de oxigênio. Os macrófagos alveolares de pacientes com DPOC secretam mais proteínas inflamatórias e têm maior atividade elastolítica quando expostos a fumaça do cigarro (Barnes et al., 2003). 
Além disso, há um aumento no número total de linfócitos $T$ no parênquima pulmonar e nas vias aéreas centrais e periféricas, principalmente CD8+ em pacientes enfisematosos (Barnes et al., 2003).

Na DPOC o papel dos eosinófilos ainda não está muito bem esclarecido. Proteínas básicas de eosinófilos estão presentes no escarro de pacientes com DPOC, sugerindo que ocorre degranulação nestas células devido a altos níveis de elastase neutrofílica (Barnes et al., 2003).

Já as células epiteliais são, na DPOC, importantes fontes de mediadores inflamatórios, como TNF-a e IL-8, sendo ativadas pelo fumo do tabaco. Nas pequenas vias aéreas são fonte de TGF- $\beta$, que induz fibrose local (Barnes et al., 2003).

\subsubsection{Papel da MMP12 na DPOC}

As metaloproteases de matriz são endopeptidases que formam uma família de enzimas proteolíticas. Elas são responsáveis pela degradação dos componentes da matriz extracelular que levará ao processo de reparo tecidual e consequente remodelamento do parênquima pulmonar (Chaudhuri et al., 2012).

A MMP-12 foi reconhecida como importante na indução do enfisema, primeiramente em camundongos. Em um estudo com camundongos knockout para o gene da MMP-12 os animais não apresentaram aumento no número de macrófagos nos pulmões e não desenvolveram enfisema quando expostos a fumaça de cigarro (Hautamaki et al., 1997). Posteriormente, foi demonstrado 
aumento dos níveis da expressão desta MMP em pacientes DPOC (Molet et al., 2005).

Isso sugere que a MMP12 não só está correlacionada à destruição da matriz extracelular e consequente remodelamento como também ao processo de recrutamento de mais macrófagos na resposta inflamatória a exposição a fumaça de cigarro (Churg et al., 2007).

\subsubsection{Macrófagos alveolares}

Segundo Martinez (2009), os macrófagos são células da resposta imune inata com diversas funções bem estabelecidas, agem na resposta primária frente aos diversos patógenos, na homeostase, na coordenação da resposta imune adaptativa, na inflamação, na resolução e no reparo dos tecidos. Estas células reconhecem "sinais de perigo" através de receptores capazes de induzir programas de ativação especializados e podem assumir fenótipos diferentes dependendo do contexto imunológico.

Estas células exercem função fagocitária tanto no tecido intersticial do septo alveolar quanto no lúmen do alvéolo, sobre partículas orgânicas e inorgânicas. Após completarem a fagocitose do agente invasor, os macrófagos podem alcançar os bronquíolos sendo eliminados pelo sistema mucociliar, ou penetrar no septo alveolar, alcançando os vasos linfáticos e atingindo os linfonodos correspondentes (Martinez et al., 2009)

Esse tipo celular tem um papel importante na resposta inflamatória na DPOC participando não só da fagocitose de agentes estranhos como também da ativação e liberação de substâncias, como ativação de neutrófilos e 
recrutamento de mais macrófagos e liberação de metaloproteinases, interleucinas e TNF- $\alpha$, entre outras (Movahedi et al., 2010).

\subsubsection{Estresse Oxidativo}

As espécies reativas de oxigênio (EROs) representam uma família diversa de moléculas envolvidas em processos fisiológicos e fisiopatológicos. São geradas durante uma sequência de reações oxidativas, em que há um aumento no consumo de oxigênio, provocado pela ativação da NADPH oxidase, a qual reduz o oxigênio a ânion superóxido. Este ânion é o precursor primário das EROs, que podem ser divididas em: radicais livres de oxigênio espécies altamente instáveis e de vida curta - como o ânion superóxido $\left(\mathrm{O}_{2}^{-}\right)$, oxigênio singlete $\left({ }^{1} \mathrm{O}_{2}\right)$ e radical hidroxila $(\mathrm{OH})$ e radicais mais estáveis e oxidantes não-radicalares como ácido hipocloroso $(\mathrm{HOCl})$, peróxido de hidrogênio $\left(\mathrm{H}_{2} \mathrm{O}_{2}\right)$ e ozônio $\left(\mathrm{O}_{3}\right)$ (Babior, 1999; Quinn et al., 2006).

Nos últimos anos, muito se avançou no estudo das NADPH oxidases e hoje já está claro que as espécies reativas de oxigênio liberadas por esta enzima, constituem importantes reguladores de vias de sinalização celular, através da modulação da atividade de quinases e fosfatases ou através da regulação da transcrição gênica (Groemping and Rittinger, 2005).

Embora façam parte de várias vias de sinalização celular, a produção excessiva de EROs resulta no estresse oxidativo, um processo deletério que pode causar danos em estruturas celulares e seus constituintes, incluindo lipídeos, membranas, proteínas e DNA (Valko et al., 2007). As EROs estão envolvidas na progressão de vários processos patológicos, como a hipertensão 
e a aterosclerose (Grote et al., 2006; Cave et al., 2006), artrite reumatóide, isquemia tecidual, doenças renais (El-Benna, et al., 2005) e câncer (Valko et al., 2007). A evolução dessas patologias deve-se a dois fatores: alteração do balanço redox da célula ou ao aumento da atividade da NADPH oxidase levando a condições inflamatórias. Além disso, o processo de envelhecimento também está relacionado aos danos causados pelas EROs, como peroxidação lipídica, danos ao DNA e oxidação protéica (Harman, 1956).

Em fumantes, os macrófagos alveolares liberam mais espécies reativas de oxigênio que em não fumantes e a capacidade antioxidante do plasma está reduzida devido ao uso do cigarro (Wright et al., 1999). O aumento da liberação de espécies reativas de oxigênio traz consequências como aumento da oxidação de anti-proteases, como a a1-AT, podendo, através da ativação de MMPs, aumentar a proteólise e consequentemente a destruição do parênquima pulmonar levando ao enfisema (Barnes et al., 2003).

\subsubsection{Apoptose de células estruturais}

A apoptose é um processo de regulação da morte celular, permitindo a eliminação de células infectadas ou danificadas que precisam ser removidas do organismo; no entanto se estas células não forem devidamente eliminadas e permanecerem no tecido ocorrerá o rompimento do citoplasma destas com consequente liberação de mediadores inflamatórios no tecido em questão, aumentando a progressão da doença (Aoshiba et al., 2003). 
O papel da apoptose na patogênese da DPOC tem sido foco de estudos que vêm utilizando fragmentos de pulmões de pacientes que apresentam esta doença. Segura-Valdez et al. (2000) encontraram um aumento da apoptose de células endoteliais em pulmões de pacientes com DPOC. Imai et al. (2005) também observaram aumento de células apoptóticas (células epiteliais e endoteliais) em pulmões de pacientes enfisematosos, juntamente com aumento da atividade de caspase-3. Yokohori et al. (2004) encontraram aumento de apoptose de células epiteliais em pacientes com enfisema fumantes comparados aos enfisematosos que não fumavam. Em modelo experimental, Aoshiba et al. (2003) fizeram administração intratraqueal de caspase-3 em camundongos e observaram apoptose de células das paredes alveolares, predominantemente de células epiteliais com posterior destruição destas paredes e alargamento dos espaços aéreos distais.

O grande desafio nos estudos que contemplam o entendimento da fisiopatologia da DPOC é entender até que ponto estes mecanismos ocorrem de forma isolada e como a interação entre eles interfere no desenvolvimento da doença.

\subsection{Modelos experimentais de enfisema pulmonar}

Considerando que o estudo da fisiopatologia da DPOC em seres humanos é restrito ao uso de observações morfológicas e moleculares em fragmentos de tecido de pulmões retirados de pacientes submetidos a procedimentos cirúrgicos; ou estudos in vitro limitados a um único tempo, existe uma grande expectativa do uso de modelos desenvolvidos em animais de laboratório para o estudo da patogênese, das mudanças funcionais e dos 
efeitos de possíveis fármacos como novos tratamentos, sendo que estes estudos podem ser feitos in vivo. Entretanto, é de extrema importância considerar as vantagens e desvantagens da utilização de cada um destes modelos por estes não serem espontâneos da doença e que até o momento não se encontrou um modelo experimental ideal que mimetize por inteiro o fenótipo da doença. Os dois modelos experimentais de DPOC mais utilizados são os que utilizam instilação de proteases e exposição à fumaça de cigarro.

\subsubsection{Instilação de Proteases}

Por muito tempo, usou-se a instilação ou inalação de papaína para a indução de enfisema, porém a sua atividade proteolítica é inespecífica e depende em muito do seu grau de pureza que pode variar de amostra para amostra. Atualmente, a maior parte dos estudos utiliza a elastase pancreática de porco (PPE) e a elastase de neutrófilos humanos (Lieberman et al., 1976; Jannof et al., 1985; Jannof et al., 1979).

A instilação de proteases requer apenas uma única instilação e a gravidade da doença pode ser determinada pela concentração da protease em questão.

Esse modelo é fácil de ser reproduzido, e em apenas 3 semanas pode se obter lesão e remodelamento do parênquima pulmonar, o que o torna relevante principalmente para estudos que têm por principal objetivo avaliar as alterações provocadas nas fibras do parênquima pulmonar (Jannof et al., 1985; Jannof et al., 1979). 
No entanto é importante ter um cuidado especial para a escolha da espécie animal, a idade destes animais e qual enzima serão utilizadas (Wright et al., 2008; Wright et al., 1994; Churg et al., 2007).

\subsubsection{Exposição à Fumaça de Cigarro}

É o modelo considerado o mais próximo do observado em humanos, uma vez que o cigarro é a principal causa de desenvolvimento de DPOC (Wright et al., 2008). Há uma grande variedade de máquinas de exposição à fumaça. Algumas delas usam exposição de corpo inteiro, vista de forma negativa por haver também a ingestão de nicotina quando os animais limpam seu pêlo, e outras dispõem os animais de forma que somente o nariz fique exposto ao agente tóxico (Wright et al., 2008).

Todos os modernos estudos de DPOC induzida pelo cigarro utilizam pequenos animais de laboratório incluindo, camundongos, ratos e cobaias (porquinho da Índia). As cobaias oferecem inúmeras vantagens, incluindo enfisema facilmente reconhecível, remodelamento das vias aéreas mais acentuadas do que em animais menores e o desenvolvimento considerável de metaplasia das células caliciformes. Suas principais desvantagens são o custo, a falta de ferramentas para os estudos moleculares e o número limitado de anticorpos comerciais que reagem às proteínas desses animais (Wright et al., 1990; Wright et al., 2006). 
Os ratos são bastante resistentes ao desenvolvimento da DPOC, muitos investigadores demonstram que esses animais não adquirem a doença mesmo fumando por muito tempo (Wright et al., 2008).

Os modelos recentes têm utilizado com sucesso os camundongos para o estudo da DPOC. O estudo detalhado dos pulmões é difícil, porém possível nesses animais. Eles oferecem a vantagem de ter baixo custo, uma disponibilidade extensa de proteínas, genes e anticorpos e o mais importante, numerosas linhagens que naturalmente respondem diferentemente a fumaça do cigarro, além de animais com alterações genéticas para o estudo de processos específicos na DPOC.

Além da lesão do parênquima pulmonar, nesse tipo de exposição pode ser reproduzidos a hipertensão pulmonar e o remodelamento das pequenas vias aéreas (Wright et al., 2008). A utilização deste modelo requer tempo longo de exposição dos animais (pelo menos 6 meses), e ainda assim, não é possível se observar um grau de doença grave (Fabbri et al., 2003; Rabe et al., 2007).

Outro problema importante deste modelo é que no momento em que se encerra a exposição destes animais, não existe a progressão da doença, ao contrário do que é observado em humanos (Wright et al., 1994). 


\subsubsection{Animais modificados geneticamente}

A utilização de animais geneticamente modificados permite a investigação dos efeitos de um determinado gene/proteína em diferentes tipos de lesões anatômicas de DPOC e também são úteis na elaboração de agentes terapêuticos (Wright et al., 2008).

\subsubsection{Apoptose}

Estudos que induziram apoptose através da inibição de receptores para fator de crescimento endotelial (VEGF) (Kasahara et al., 2000) ou do complexo VEGF-VEGF-R, contribuíram para a ideia de que o enfisema pode ocorrer devido a uma falha do sistema na remoção das células que entraram em apoptose e, por conseguinte, sofrem rompimento do citoplasma e liberação de agentes inflamatórios. A apoptose, nesse modelo, pode ser induzida por instilação intratraqueal de caspase-3 ativada (Aoshiba et al., 2003).

É um modelo no qual se observa o aumento de espaços aéreos distais ("enfisema") e remodelamento vascular em um curto espaço de tempo. No entanto, esse "enfisema" causado não é permanente e não há remodelamento de vias aéreas. 


\subsubsection{Privação de Alimento}

Em humanos, a privação de alimento parece estar associada à alterações semelhantes às encontradas no enfisema pulmonar.

O modelo de privação de alimento em ratos tem variado quanto ao valor da alimentação reduzida e também apresentam diferentes graus de alteração na estrutura do pulmão e alterações fisiológicas (Sahebjami et al., 1986; Sahebjami et al., 1982).

É um modelo de curto prazo com resultados relativamente consistentes. Entretanto, as alterações fisiológicas não correspondem às humanas, e pode representar um modelo de manutenção/reparação anormal do pulmão.

\subsubsection{Instilação de LPS}

LPS é um componente glicoproteico de bactérias gram-negativas e é usado devido aos seus efeitos pró-inflamatório. Está presente como um contaminante na fumaça do cigarro, poluição do ar e poeiras orgânicas (Wright et al., 2008).

Em humanos, a exposição à poeira de LPS, diminui as funções pulmonares. Com a administração crônica durante várias semanas, a instilação de LPS produz o alargamento dos espaços aéreos distais e remodelamento das vias aéreas com diminuição da espessura de suas paredes (Harkema et al., 1993; Vernooy et al., 2002).

Kobayashi et al. (2013), demonstraram que uma única instilação intratraqueal de LPS em camundongos que receberam instilação de elastase 
pancreática de porco promoveu migração de células inflamatórias, especialmente as células T CD8+ para os espaços alveolares, com aumento da produção de metaloprotease-9 e perforina no lavado broncoalveolar.

Até o momento são poucos os estudos que avaliam o efeito do LPS em modelo experimental de exposição à fumaça de cigarro. Isto decorre do fato de que embora o modelo de fumo seja considerado o que melhor mimetize o enfisema encontrado em humanos, este tipo de exposição requer um tempo bastante prolongado e a lesão tecidual obtida é considerada leve, correspondente a uma DPOC estágios I ou II (Churg et al., 2008) 


\section{JUSTIFICATIVA}

Apesar de já existirem estudos contemplando a utilização de modelos experimentais de enfisema pulmonar para tentar mimetizar as características fisiopatológicas desta doença em humanos, os mais descritos na literatura são os que utilizam a instilação de elastase pancreática de porco e a exposição à fumaça de cigarro. No entanto, estas duas formas de indução, apresentam limitações e não mimetizam totalmente o fenótipo da doença. O modelo que utiliza a instilação de elastase produz uma lesão pulmonar bastante significativa, permitindo a observação de alterações tanto da função pulmonar quanto da estrutura da matriz extracelular constituinte do parênquima. Ele é considerado o mais distante do observado em humanos pelo fato de primeiro causarmos uma lesão tecidual, para depois, observarmos um processo inflamatório decorrente deste processo de lesão. Já o modelo que faz uso da fumaça de cigarro, apesar de ser considerado o mais próximo do observado em humanos, do ponto de vista fisiopatológico, sua forma de indução requer muitos meses de exposição e o grau de lesão tecidual obtido é considerado moderado em comparação a observação em humanos doentes e ao modelo de indução por elastase. No entanto, na indução por exposição ao cigarro, o processo inflamatório aparece antes da destruição tecidual com um comprometimento das vias aéreas. Desta forma, tornou-se importante o estudo de um novo modelo experimental que contemple um processo inflamatório inicial para depois obtermos lesão do parênquima decorrente desta inflamação e que esta lesão seja maior do que as já observadas nos estudos de exposição ao tabagismo. Para evitar que ocorra um processo de destruição tecidual 
somente pela instilação de elastase, utilizamos uma dose mais baixa desta protease, que acreditamos apenas aumentar o desequilíbrio protease/antiprotease levando, desta forma, a uma maior susceptibilidade à inflamação e lesão tecidual causada pela exposição à fumaça de cigarro. 


\section{OBJETIVO}

O objetivo principal deste estudo foi desenvolver um novo modelo de enfisema experimental que utilize a instilação de elastase, em uma dose bem mais baixa do que a utilizada na literatura, em conjunto com a exposição à fumaça de cigarro, por um tempo menor do que o habitual. Acreditávamos que com a instilação prévia de uma dose baixa de elastase, haveria uma predisposição maior ao desenvolvimento de inflamação causada pela exposição ao fumo com o aparecimento de uma lesão do parênquima pulmonar maior e mais precoce do que a observada em modelos que utilizam somente a exposição ao fumo. A intenção de unir os dois modelos experimentais, já amplamente descritos, foi possibilitar a presença tanto do componente inflamatório inicial, observado nos modelos de exposição à fumaça de cigarro, quanto de uma maior lesão tecidual observada nos modelos de indução por elastase. 


\section{MÉTODOS}

\subsection{Animais}

Foram utilizados 50 camundongos C57BI/6 machos, com idade de 6-8 semanas, pesando entre 20-25g, provenientes do Biotério Central da Faculdade de Medicina da USP (FMUSP). Os animais receberam os cuidados necessários de acordo com o "Guia de cuidados e uso de animais de laboratório" (NIH publication 85-23, revisado em 1985) e com a Lei Arouca (Lei 11.794 de 8 de outubro de 2008). Foram excluídos do projeto os animais que não se adequaram aos critérios mencionados acima.

Os animais foram acondicionados em baias específicas para camundongos (aproximadamente 8 animais/baia) com as seguintes medidas (425 X 266 X $185 \mathrm{~mm}$ ) no Biotério do LIM-20 (Laboratório de Terapêutica Experimental I) da FMUSP. Foram alimentados ad libitum e mantidas em ciclo claro-escuro de 12 horas em temperatura ambiente de $20 \pm 2^{\circ} \mathrm{C}$, por profissional treinado e capacitado. Este mesmo profissional foi responsável pelos cuidados com os animais durante o período de estada destes no Biotério do Laboratório de Terapêutica Experimental-LIM-20.

Todas as atividades deste projeto foram realizadas nas dependências do LIM-20 que já possui todos os recursos e infraestrutura necessários às realizações deste protocolo. 


\subsection{Instilação intranasal de elastase pancreática de porco}

A indução do enfisema pulmonar foi realizada utilizando elastase pancreática de porco (PPE) (Elastase Type I/ E-1250, Sigma Aldrich). Cada animal foi devidamente anestesiado através de aplicação intramuscular de Xylazina (5 mg/Kg) e Ketamina $(40 \mathrm{mg} / \mathrm{kg}$ ) e recebeu $50 \mu \mathrm{l}$ de solução de elastase com uma concentração de 0,33UI, através de instilação intranasal. Nos grupos controles, os animais receberam instilação nasal de solução fisiológica (SF) $(0,9 \% \mathrm{NaCl})$, veículo da elastase.

\subsection{Exposição à fumaça de cigarro}

Os animais foram expostos à fumaça de cigarro por $30 \mathrm{~min} / \mathrm{dia}, 5$ vezes/ semana por 2 meses. A exposição foi realizada em uma câmara inalatória, sendo esta uma caixa de plástico de 28 litros (L) (aproximadamente 40x27 cm na base, com altura de $26 \mathrm{~cm}$ ) com duas entradas de ar: uma para ar sintético e outra para entrada da fumaça de cigarro e na parte superior desta caixa houve um pequeno ventilador para homogeneização do ar (Biselli et al. 2011).

O fluxo de ar, no interior da caixa foi controlado por um fluxômetro conectado a um torpedo de ar comprimido e foi mantido em $2 \mathrm{~L} / \mathrm{min}$. A segunda entrada de ar recebeu uma mistura de ar sintético e fumaça de cigarro, que foi aspirada por um sistema de Venturi conectado ao cigarro aceso. O fluxo laminar de ar sintético passou por uma região de menor diâmetro, desta forma, houve uma aceleração do fluxo e consequente redução da pressão neste ponto (efeito Venturi), permitindo a aspiração da fumaça do cigarro. A redução na 
pressão que ocorre no ponto de redução do diâmetro do tubo é dependente do fluxo de ar que será mantido constante (Figura 1).

Foi mantida uma concentração de monóxido de carbono variando 250 a 350 ppm (ToxiPro, biosystems, USA), baseados em estudo prévio desenvolvido em nosso laboratório (Biselli et al., 2011).

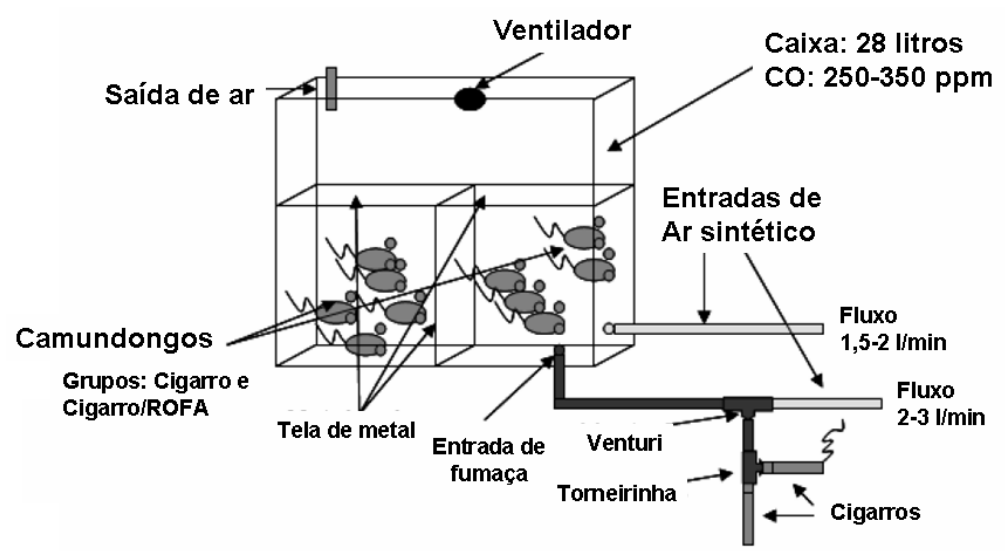

Figura 1: Esquema ilustrativo da caixa de exposição à fumaça de cigarro (adaptado de Biselli, 2011)

\subsection{Grupos experimentais}

Os animais foram divididos aleatoriamente nos seguintes grupos:

- Grupo Controle 2 meses: Animais que receberam instilação de SF (Solução Fisiológica) e foram sacrificados 2 meses após a instilação, n=9 animais.

- Grupo Elastase 2 doses 2 meses: Animais que receberam instilação intranasal de metade da dose usual de elastase no primeiro dia e depois de transcorrido 1 mês de experimento novamente. Foram sacrificados após 2 meses, $\mathrm{n}=9$ animais. 
- Grupo Fumo + Elastase 1 dose 2 meses: Animais receberam instilação intranasal de metade da dose usual de elastase no primeiro dia de experimento e foram expostos à fumaça de cigarro durante dois meses, 2 vezes ao dia, por 30 minutos cada vez, 5 dias na semana. Foram sacrificados após 2 meses, $\mathrm{n}=10$ animais.

- Grupo Fumo + Elastase 2 doses 2 meses: Animais que receberam instilação intranasal de metade da dose usual de elastase no primeiro dia e depois de transcorrido 1 mês de experimento e foram expostos à fumaça de cigarro durante dois meses, 2 vezes ao dia, 30 minutos cada vez, 5 dias na semana. Foram sacrificados após 2 meses, $n=10$ animais.

- Grupo fumo 2 meses: Animais que foram expostos à fumaça de cigarro durante dois meses, 2 vezes ao dia, 30 minutos cada vez, 5 dias na semana. Foram sacrificados após 2 meses, $n=10$ animais.

\subsection{Avaliação da Mecânica Respiratória}

Seguindo o cronograma designado para cada grupo, os animais de cada grupo foram anestesiados com Thiopental (50 mg/kg, por via intraperitoneal), traqueostomizados com um cateter intravascular $20 \mathrm{G}$ e conectados a um respirador para pequenos animais (flexiVent, SCIREQ, Montreal, Canada). Um diagrama esquemático do respirador mecânico utilizado é apresentado na Figura 2.

Os animais foram ventilados com um volume corrente de $10 \mathrm{~mL} / \mathrm{kg}$ e freqüência respiratória de 120 ciclos/minuto. Foi calculada a impedância do sistema respiratório (Zrs) dos animais de cada grupo, para tanto foi utilizado um 
sinal de perturbação em volume de 16 segundos. A ventilação mecânica foi interrompida somente para a aplicação das perturbações. Após a perturbação, os dados foram coletados.

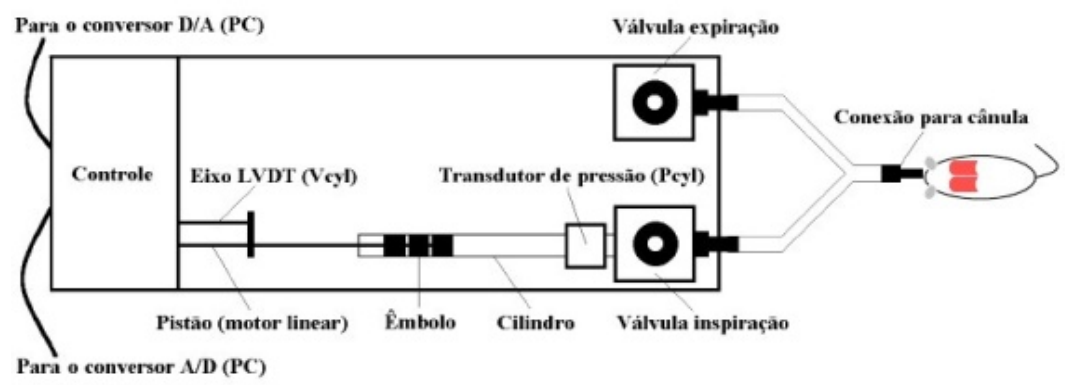

Figura 2: Esquema do respirador para pequenos animais (Flexivent-Scireq)

Para análise das impedâncias obtidas, utilizamos o modelo de fase constante, descrito por Hantos (1992).

$$
Z(f)=R_{a w}+i \cdot 2 \cdot \pi \cdot f \cdot I_{a w}+\frac{G-i \cdot H}{(2 \cdot \pi \cdot f)^{\alpha}}
$$

O Raw é a resistência de vias aéreas, law é a inertância das vias aéreas, Gtis caracteriza a dissipação de energia nos tecidos pulmonares, Htis caracteriza a energia acumulada nos tecidos do pulmão, $i$ é a unidade imaginária, $f$ é a frequência e $e^{\alpha=\frac{2}{\pi} \cdot \arctan \left(\frac{H}{G}\right)}$.

O parâmetro Raw (resistência de vias aéreas), nos permite a análise, isoladamente das vias aéreas, sem a interferência do tecido pulmonar. $O$ parâmetro Gtis avalia a resistência tecidual, enquanto que o parâmetro Htis seria a elastância do tecido pulmonar. 


\subsection{Análise do Lavado Broncoalveolar (BAL)}

Após a coleta dos dados de mecânica respiratória, os pulmões foram lavados com $1,5 \mathrm{~mL}$ de solução salina $0,9 \%$ e grande parte deste volume foi recuperado para posteriores análises dos tipos celulares. Este volume recuperado, o lavado bronco alveolar $(B A L)$, foi então centrifugado a 1000 rpm por 10 minutos, o sobrenadante foi armazenado a $-20^{\circ} \mathrm{C}$ e o botão celular ressuspenso em HBSS $+0,1 \%$ BSA (bovine serum albumin) para contagem das células em câmara de Neubauer. Alíquotas da suspensão celular foram centrifugadas em lâminas de vidro usando uma citocentrífuga e coradas com Giemsa. A contagem de 300 células foi feita em campos aleatoriamente selecionados. Para obtenção do número absoluto de cada população celular no $\mathrm{BAL}$, as porcentagens foram multiplicadas pelo número total de células encontradas no volume.

Os animais foram posteriormente sacrificados por meio de exsanguinação da veia cava inferior para retirada dos pulmões. Ao final, a caixa torácica foi aberta para retirada dos pulmões e coração em monobloco.

\subsection{Retirada e Fixação dos Pulmões para Histologia}

Os pulmões foram fixados em formaldeído (4\%) sob pressão constante de $20 \mathrm{cmH}_{2} \mathrm{O}$ por 24 horas. Após a fixação foram feitos cortes destes pulmões para análise histológica e colorações com Hematoxilina-Eosina (avaliação do diâmetro alveolar médio). 


\subsection{Análise imunohistoquímica}

Para realizar a imunohistoquímica, as lâminas silanizadas foram desparafinizadas em xilol quente por 30 minutos a $60-65^{\circ} \mathrm{C}$ e reidratadas em concentrações decrescentes de etanol, água corrente e água destilada por três minutos cada. Os epítopos antigênicos foram recuperados por alta temperatura em solução de citrato $10 \mathrm{mM}(\mathrm{pH}=6,0)$ em panela de pressão. Posteriormente, os sítios inespecíficos reativos a oxidação foram bloqueados com peroxidase endógena em temperatura ambiente para inativação de epítopos inespecíficos. Em seguida, as lâminas foram incubadas durante a noite a $4^{\circ} \mathrm{C}$ com anticorpo primário. Após este período, os cortes foram lavados com tampão fosfato (PBS - $\mathrm{pH}=7,4)$ e incubados com anticorpo secundário de acordo com a origem do anticorpo primário, por 30 minutos a $37^{\circ} \mathrm{C}$. Em seguida, as lâminas foram incubadas em câmara úmida com complexo conjugado com peroxidase (Vector Laboratories - Sta. Cruz Biotechnology, CA, EUA) por 30 minutos a $37^{\circ} \mathrm{C}$. Finalmente, para a revelação foi utilizada solução de cromógeno (DAB) e Hematoxilina de Harris para contracorar. As lâminas foram montadas com lamínulas e resina sintética.

Para cada marcador específico foi utilizado um determinado anticorpo com seu respectivo anticorpo secundário, os quais estão descritos na tabela a seguir: 


\begin{tabular}{|c|c|c|c|c|}
\hline Marcador & $\begin{array}{c}\text { Anticorpo } \\
\text { Primário }\end{array}$ & $\begin{array}{c}\text { Anticorpo } \\
\text { Secundário }\end{array}$ & Diluição & Especificação \\
\hline MAC-2 & $\begin{array}{c}\text { Monoclonal } \\
\text { produzido em } \\
\text { rato IgG2a }\end{array}$ & Anti-rat & $1: 50.000$ & $\begin{array}{c}\text { Clone M3/38; Cedarlene } \\
\text { Laboratories, Ontário, } \\
\text { Canadá }\end{array}$ \\
\hline MMP12 & $\begin{array}{c}\text { Policlonal } \\
\text { produzido em } \\
\text { cabra IgG }\end{array}$ & Anti-goat & $1: 500$ & $\begin{array}{c}\text { SC-8839 Goat } \\
\text { Polyclonal; Sta. Cruz } \\
\text { Biotechnology, Ca, USA }\end{array}$ \\
\hline Caspase 3 & $\begin{array}{c}\text { Policlonal } \\
\text { produzido em } \\
\text { coelho IgG }\end{array}$ & Anti-rabbit & $1: 500$ & $\begin{array}{c}\text { SC-7148 Rabbit } \\
\text { Polyclonal; Sta. Cruz } \\
\text { Biotechnology, Ca, USA }\end{array}$ \\
\hline gp91 phox & $\begin{array}{c}\text { Policlonal } \\
\text { produzido em } \\
\text { cabra IgG }\end{array}$ & Anti-goat & $1: 800$ & $\begin{array}{c}\text { SC-5827 Goat } \\
\text { Polyclonal; Sta. Cruz } \\
\text { Biotechnology, Ca, USA }\end{array}$ \\
\hline
\end{tabular}

O MAC-2 é um marcador específico para quantificação da densidade de macrófagos. Também foram feitas marcações específicas para MMP-12, Caspase-3, uma das enzimas envolvida na cascata de reações que promovem a apoptose celular, e a gp91 ${ }^{\text {phox }}$, uma subunidade da molécula de NADPH oxidase, envolvida no processo de extresse oxidativo.

\subsection{Avaliação Morfométrica}

\subsubsection{Diâmetro Alveolar Médio}

Foi utilizado morfometria convencional, por meio de um retículo (100 pontos e 50 retas) acoplado à ocular de um microscópio óptico comum. Sendo avaliado o intercepto linear médio (LM). O LM é um índice através do qual avaliamos o diâmetro médio dos espaços aéreos distais. Para tanto, foram quantificados o número de vezes que as retas do retículo cruzam as paredes 
dos alvéolos em 15 campos/lâmina. As medidas foram feitas em aumento de 200X (Margraf et al., 1991).

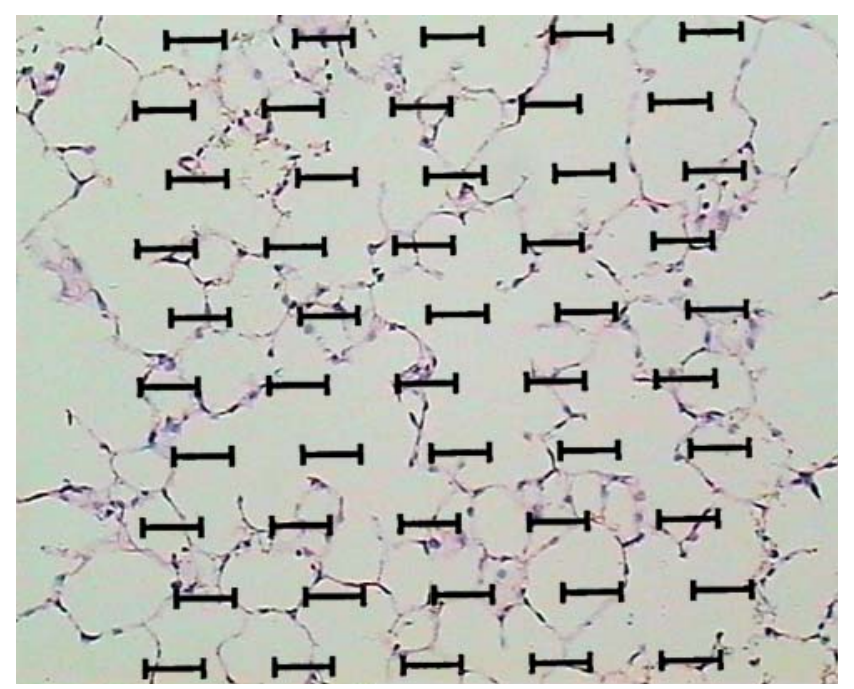

Figura 3: Fotomicrografia do retículo sobre uma lâmina (Coloração em HE e aumento de 200X)

\subsubsection{Contagem de Macrófagos (MAC2) e Células Positivas para}

\section{MMP-12, Caspase 3 e gp91 phox}

O número de células que expressam cada tipo de marcador analisado foi contado no parênquima alveolar e ao redor das vias aéreas com a ajuda de um retículo de 100 pontos e 50 retas. Utilizando o mesmo retículo de 100 pontos e 50 retas com área conhecida $\left(62.500 \mu \mathrm{m}^{2}\right.$ no aumento de $\left.400 \mathrm{X}\right)$ foi contado o número de pontos que caíam no parênquima ou ao redor das vias aéreas para cada campo escolhido. A área de tecido para cada campo foi calculada de acordo com o número de pontos que interceptavam os septos alveolares. Depois foi contado o número de células positivas que estavam na região do tecido analisada. A densidade de células foi determinada pela seguinte equação: 
Densidade de células positivas = número de células positivas / número de pontos que incidiam no parênquima/ ou ao redor das vias aéreas.

O resultado está expresso como células $/ \mu \mathrm{m}^{2}$.

Foram contados 20 campos por lâmina com um aumento de 400X.

Figura 4: Fotomicrografia do retículo sobre uma lâmina, com as células positivas marcadas em marrom (aumento de 400X)

\subsection{Análise estatística}

As análises estatísticas foram realizadas através do software SigmaStat, utilizamos o teste de Análise de Variância para um Fator (One Way ANOVA) seguido pelo teste de múltiplas comparações. Um valor de $p<0,05$ foi considerado estatisticamente significativo. 


\section{RESULTADOS}

Os dados apresentados a seguir fazem referência aos animais expostos a fumaça de cigarro por 2 meses, que não receberam PPE (Fumo), que receberam metade da dose de PPE uma única vez no primeiro dia de experimento (Fumo/Elastase 1 dose) e que receberam metade da dose de PPE 2 vezes, no primeiro dia de experimento e após 30 dias de experimento (Fumo/Elastase 2 doses) e aos grupos, Controle (Controle) que recebeu solução salina duas vezes, no primeiro dia e após 30 dias de experimento, e Elastase (Elastase) que recebeu metade da dose de PPE no primeiro dia e após 30 dias de experimento, sacrificados depois de 2 meses de experimento. Os resultados de Raw $(p=0,358)$, Gtis $(p=0,059)$ e Htis $(p=0,136)$ representados nas figuras 5, 6 e 7, respectivamente, não apresentaram diferença estatística quando os grupos foram comparados.

$\mathrm{Na}$ análise do BAL (figura 8) o número de células totais não apresentou diferença estatisticamente significativa quando os grupos foram comparados. Os valores estão expressos como média \pm EP; $p=0,557$.

A figura 9 apresenta a análise do LM demonstrando diferença estatisticamente significativa do grupo Fumo/Elastase 1 dose e Fumo/Elastase 2 doses quando são comparados aos grupos Controle e Fumo. Os valores estão expressos como média $\pm E P ; p<0,05$.

Na análise de imunohistoquímica para contagem de macrófagos (MAC2) no parênquima pulmonar os resultados apresentados na figura 10 demonstram diferença estatística entre o grupo Fumo/Elastase 2 doses quando comparado 
aos grupos Controle, Elastase e Fumo sendo $p<0,05$. Já quando esse mesmo tipo celular foi analisado nas vias aéreas (Figura 11) houve diferença tanto no grupo Fumo/Elastase 1 dose $(p<0,05)$ quanto no grupo Fumo/Elastase 2 doses $(p<0,05)$ quando comparados aos grupos Controle, Elastase e Fumo. Os valores estão expressos como média \pm EP.

Na contagem de células positivas para MMP12 no parênquima pulmonar houve diferença estatística no grupo Fumo/Elastase 2 doses (Figura 12) quando comparado ao grupo Controle, sendo $p=0,02$, mas não houve diferença estatisticamente significativa quando analisamos as vias aéreas (Figura 13) $(p=0,059)$. Os valores estão expressos como média $\pm E P$.

Na análise das células positivas para gp91 ${ }^{\text {phox }}$ no parênquima pulmonar demonstrado pela figura 14 detectamos diferença estatisticamente significativa nos grupos Fumo/Elastase 1 dose, Fumo/Elastase 2 doses e Fumo quando eles foram comparados ao grupo Controle, sendo $p<0,05$, $p<0,05$ e $p=0,028$, respectivamente. Os valores estão expressos como média \pm EP. Quando esse marcador foi analisado nas vias aéreas (Figura 15) o que observamos foi um aumento significativo nos grupos Fumo $(p<0,05)$ e Fumo/Elastase 1 dose $(p<0,05)$, quando comparados ao grupo Controle e Elastase, sendo que apesar de aparentemente o grupo Fumo/Elastase 2 doses apresentar um aumento ele não foi estatisticamente significativo. Os valores estão expressos como média \pm EP.

Na contagem de células positivas para Caspase 3 tanto no parênquima pulmonar quanto nas vias aéreas não detectamos aumento significativo dessas células (Figura 16 e 17; $p=0,872$ e p=0,472, respectivamente). Os valores estão expressos como média \pm EP. 
Quando analisamos a proporção de fibras de colágeno remanescentes no parênquima pulmonar não observamos diferença estatisticamente significativa entre os grupos (Figura 18). Os valores estão expressos como média $\pm E P ; p=0,158$. Já quando analisamos as fibras de elástica remanescentes no mesmo local (Figura 19) detectamos diferenças estatisticamente significativas no grupo Fumo/Elastase 1 dose quando foi comparado aos grupos Controle e Fumo/Elastase 2 doses $(p<0,05)$ e no grupo Fumo quando comparado ao grupo Controle $(p=0,004)$. Os valores estão expressos como média \pm EP. 


\subsection{Mecânica Respiratória}

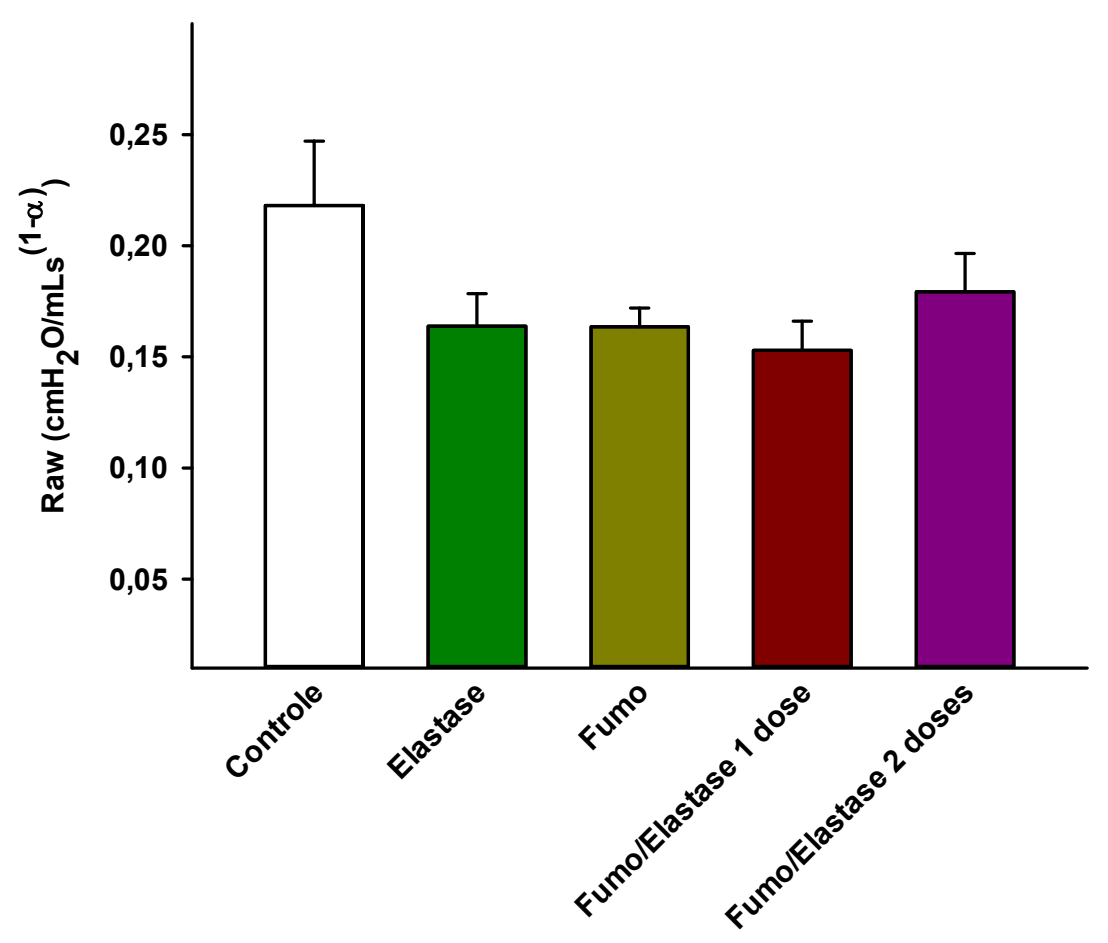

Figura 5: Resistência de vias aéreas (Raw) dos 5 grupos experimentais. Não houve diferença estatisticamente significativa entre os grupos, $p=0,358$. Os valores estão expressos como média $\pm E P$. (Controle $n=9$, Elastase $n=9$, Fumo $n=10$, Fumo/Elastase 1 dose $n=10$, Fumo/Elastase 2 doses $n=10$ )

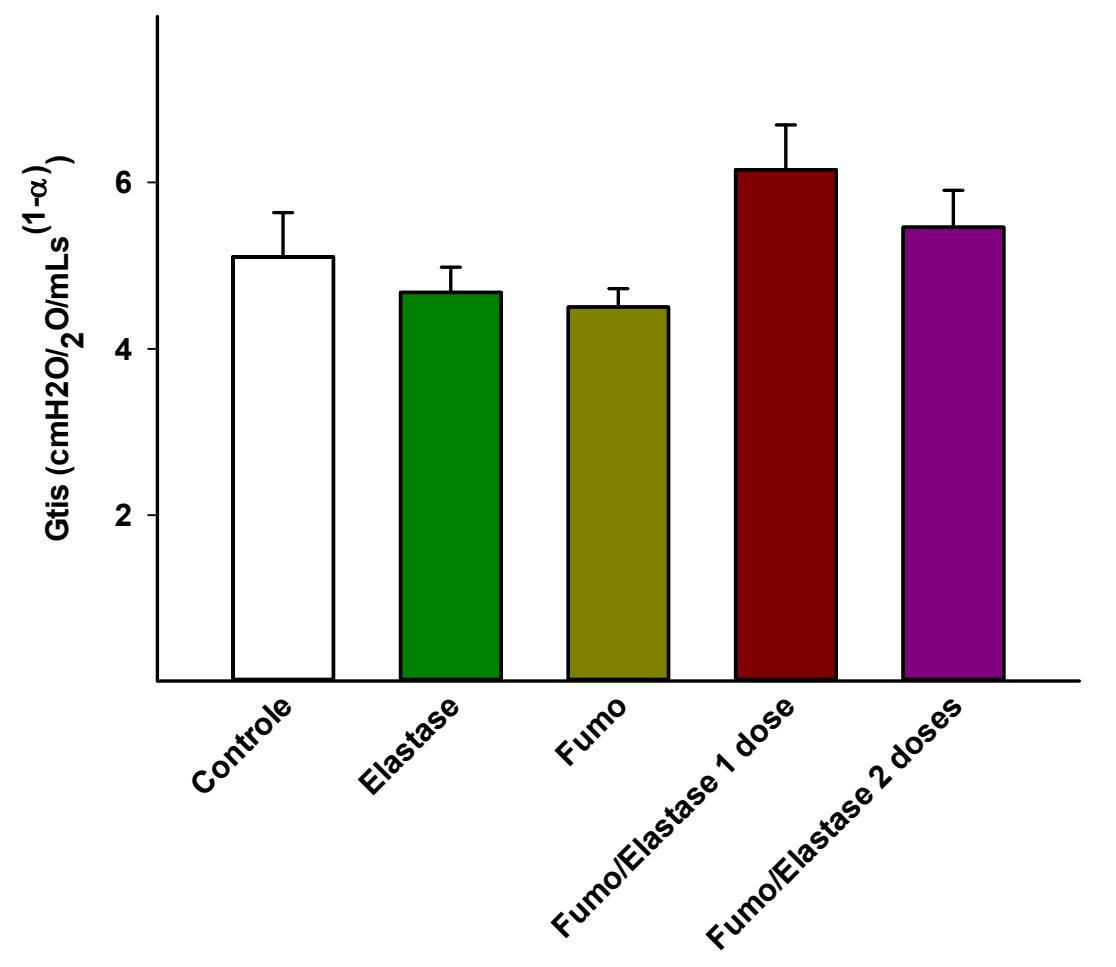

Figura 6: Resistência do tecidopulmonar (Gtis) dos 5 grupos experimentais. Não houve diferença estatisticamente significativa entre os grupos, $\mathrm{p}=0,059$. Os valores estão expressos como média $\pm E P$. (Controle $n=9$, Elastase $n=9$, Fumo $n=10$, Fumo/Elastase 1 dose $n=10$, Fumo/Elastase 2 doses $n=10$ ) 


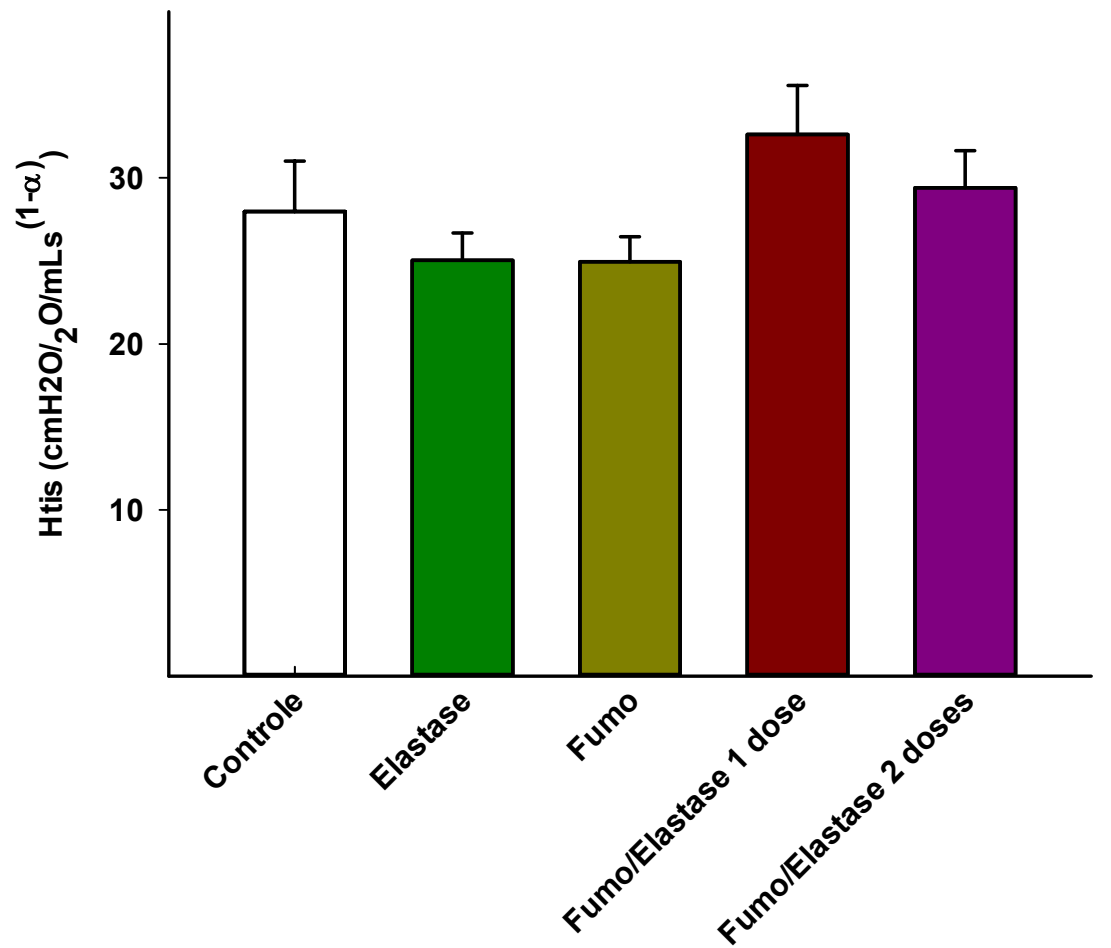

Figura 7: Elastância do tecido pulmonar (Htis) dos 5 grupos experimentais.

Não houve diferença estatisticamente significativa entre os grupos, $\mathrm{p}=0,136$.

Os valores estão expressos como média \pm EP.

(Controle $n=9$, Elastase $n=9$, Fumo $n=10$, Fumo/Elastase 1 dose $n=10$,

Fumo/Elastase 2 doses $n=10$ ) 


\subsection{Lavado broncoalveolar (BAL)}

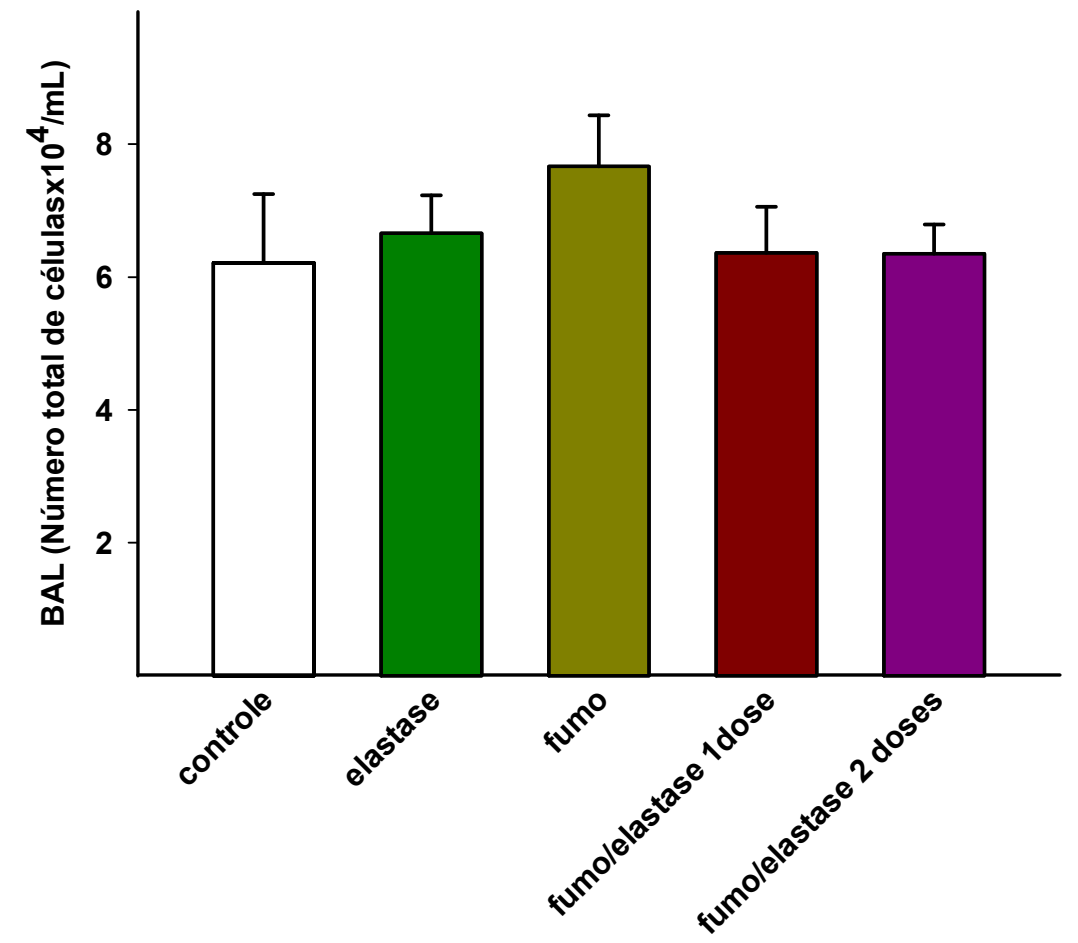

Figura 8: Na análise do lavado bronco alveolar (BAL),

Não houve diferença estatisticamente significativa entre os grupos,

$p=0,557$. Os valores são a média $\pm E P$.

(Controle $n=9$, Elastase $n=9$, Fumo $n=10$, Fumo/Elastase 1 dose $n=10$, Fumo/Elastase 2 doses $n=10$ ) 


\subsection{Intercepto Linear Médio (LM)}

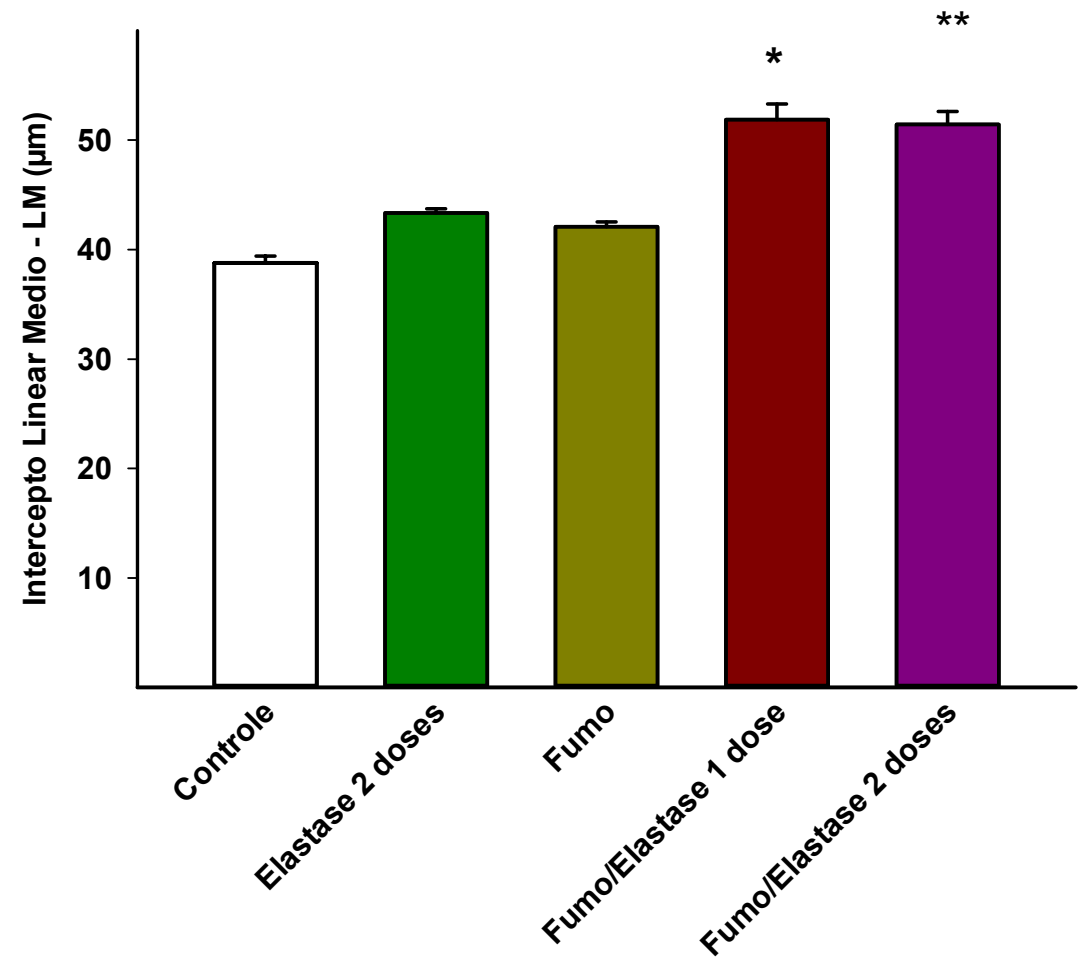

Figura 9: Valores do Intercepto Linear Médio (LM) nos 5 grupos Experimentais. Os valores estão expressos como média \pm EP.

Sendo * $\mathrm{e}^{* *}$ diferentes estatisticamente quando comparados aos grupos Controle e Fumo, com $\mathrm{p}<0,05$.

(Controle $n=9$, Elastase $n=9$, Fumo $n=10$, Fumo/Elastase 1 dose $n=10$, Fumo/Elastase 2 doses $n=10$ ) 


\subsection{Células positivas para MAC2 no parênquima pulmonar e vias aéreas}

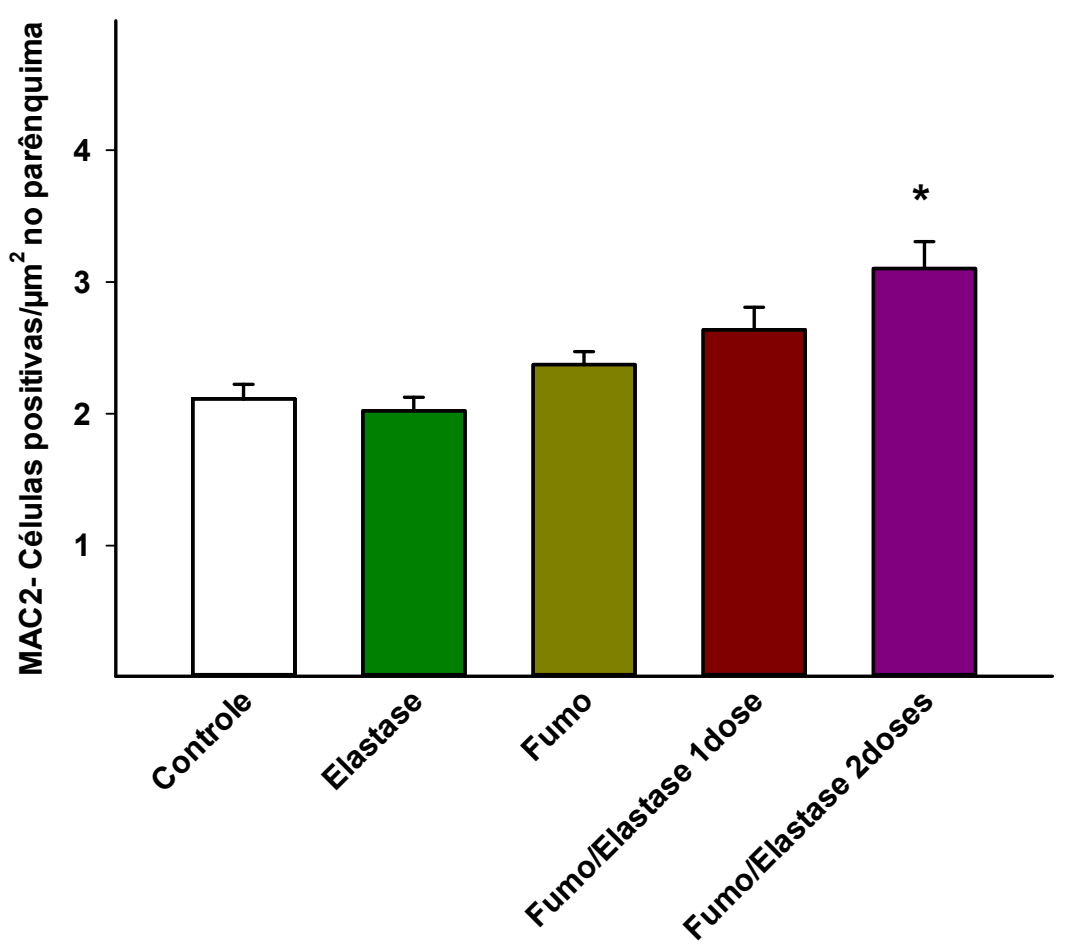

Figura 10: Contagem de macrófagos (MAC2) no parênquima pulmonar. Os valores estão expressos como média $\pm \mathrm{EP}$. ${ }^{*} p<0,05$ comparado aos grupos Controle, Elastase e Fumo.

(Controle $n=9$, Elastase $n=9$, Fumo $n=10$, Fumo/Elastase 1 dose $n=10$, Fumo/Elastase 2 doses $n=10$ )

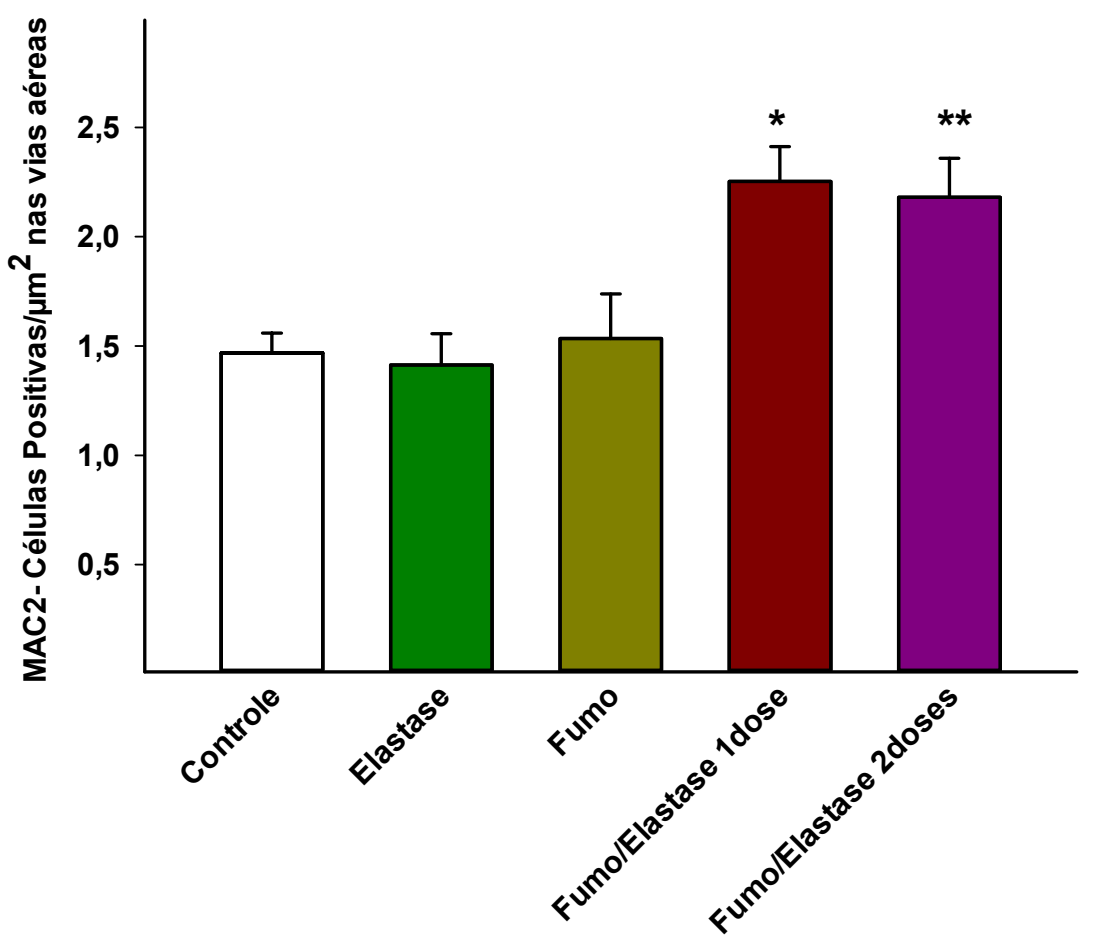

Figura 11: Contagem macrófagos (MAC2) nas vias aéreas. Os valores estão expressos como média $\pm E P$. ${ }^{*} p<0,05 e{ }^{* *} p<0,05$ comparados ao Controle, Elastase e Fumo.

(Controle $n=9$, Elastase $n=9$, Fumo $n=10$, Fumo/Elastase 1 dose $n=10$, Fumo/Elastase 2 doses $n=10$ ) 


\subsection{Células positivas para MMP12 no parênquima pulmonar e vias aéreas}

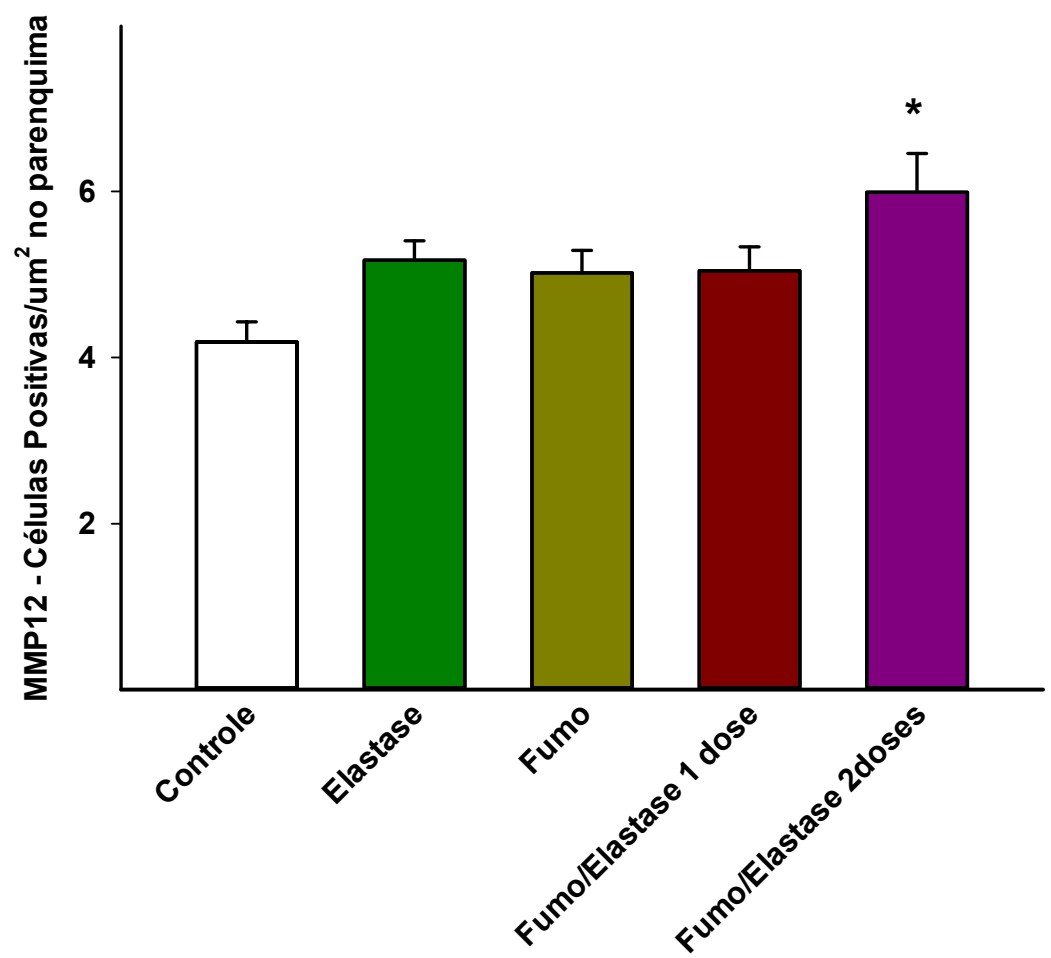

Figura 12: Contagem de células positivas para MMP12 no parênquima pulmonar. Os valores estão expressos como média $\pm \mathrm{EP}$. ${ }^{*} \mathrm{p}=0,02$ comparado ao grupo Controle.

(Controle $n=9$, Elastase $n=9$, Fumo $n=10$, Fumo/Elastase 1 dose $n=10$, Fumo/Elastase 2 doses $n=10$ )

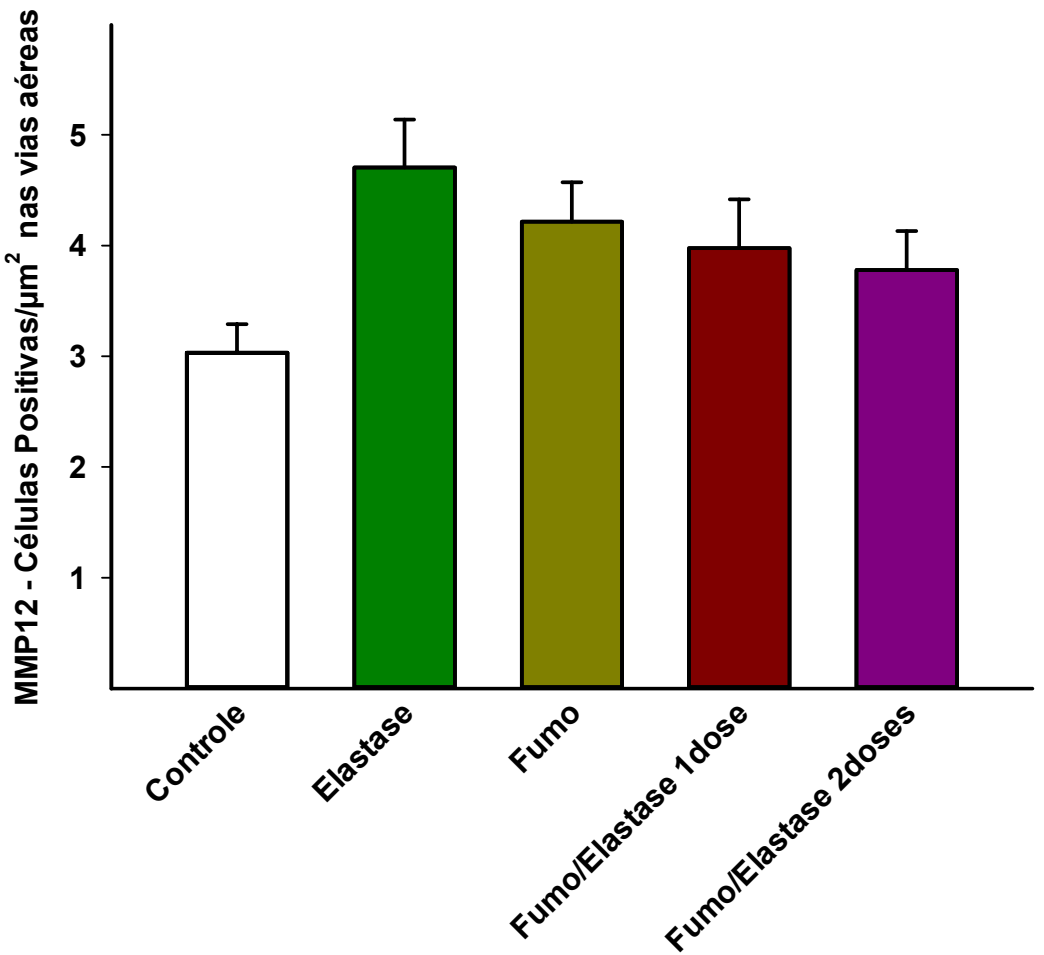

Figura 13: Contagem de células positivas para MMP12 nas vias aéreas. Os valores estão expressos como média \pm EP. Apesar de o grupo Elastase apresentar um aumento aparente, ele não foi estatisticamente significativo, quando comparado aos outros grupos, $p=0,059$.

(Controle $n=9$, Elastase $n=9$, Fumo $n=10$, Fumo/Elastase 1 dose $n=10$,

Fumo/Elastase 2 doses $n=10$ ) 


\subsection{Células positivas para GP91 $1^{\text {phox }}$ no parênquima pulmonar e vias aéreas}

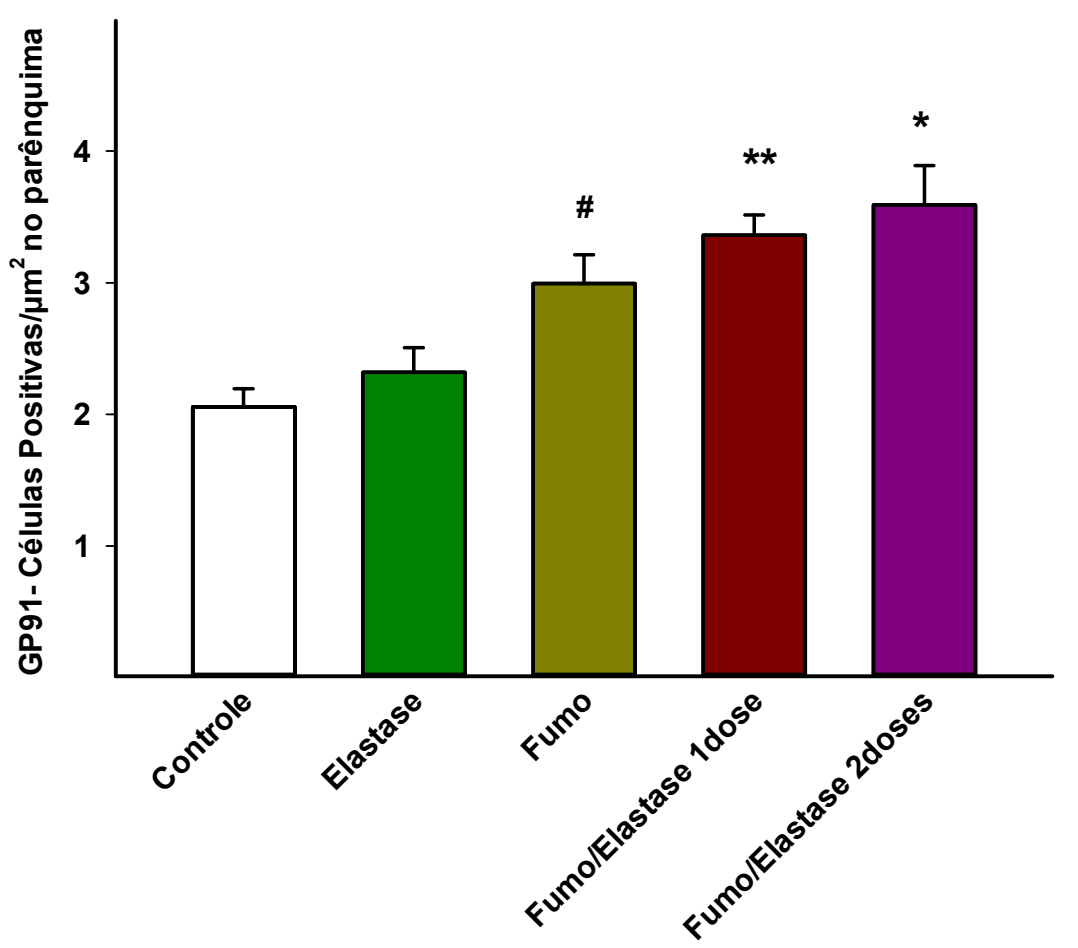

Figura 14: Contagem de células positivas para GP91 $1^{\text {phox }}$ no parênquima pulmonar. Os valores estão expressos como média \pm EP. Sendo ${ }^{*} \mathrm{p}<0,05,{ }^{* *} \mathrm{p}<0,05$, comparado aos grupos Controle e Elastase e $\# \mathrm{p}=0,028$, comparado ao grupo Controle.

(Controle $n=9$, Elastase $n=9$, Fumo $n=10$, Fumo/Elastase 1 dose $n=10$, Fumo/Elastase 2 doses $n=10$ )

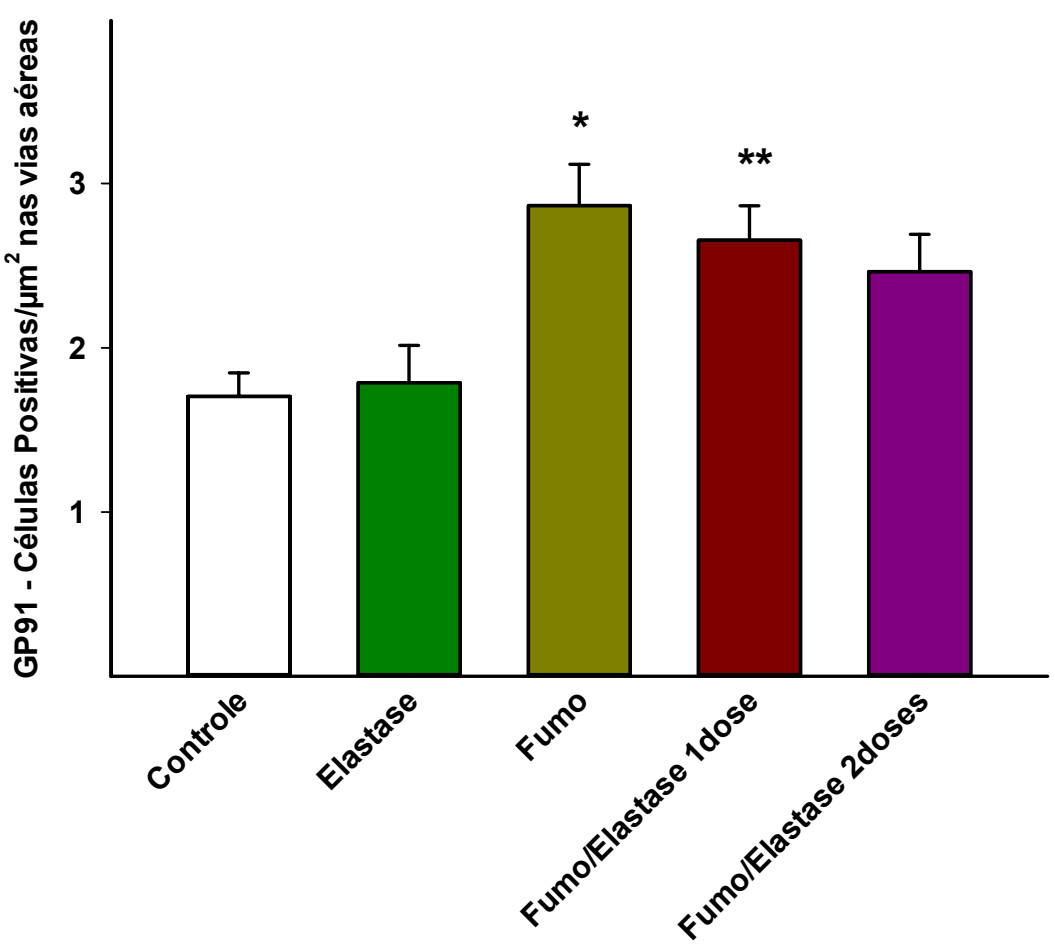

Figura 15: Contagem de células positivas para GP91phox nas vias aéreas. Os valores estão expressos como média $\pm E P$. Sendo * $p<0,05$ e ${ }^{* *} \mathrm{p}<0,05$, quando comparados aos grupos Controle e Elastase. Apesar de o grupo Fumo/Elastase 2 doses apresentar um aumento aparente em relação ao Controle ele não foi estatisticamente significativo.

(Controle $n=9$, Elastase $n=9$, Fumo $n=10$, Fumo/Elastase 1 dose $n=10$, Fumo/Elastase 2 doses $n=10$ ) 
5.6 Células positivas para Caspase 3 no parênquima pulmonar e vias aéreas

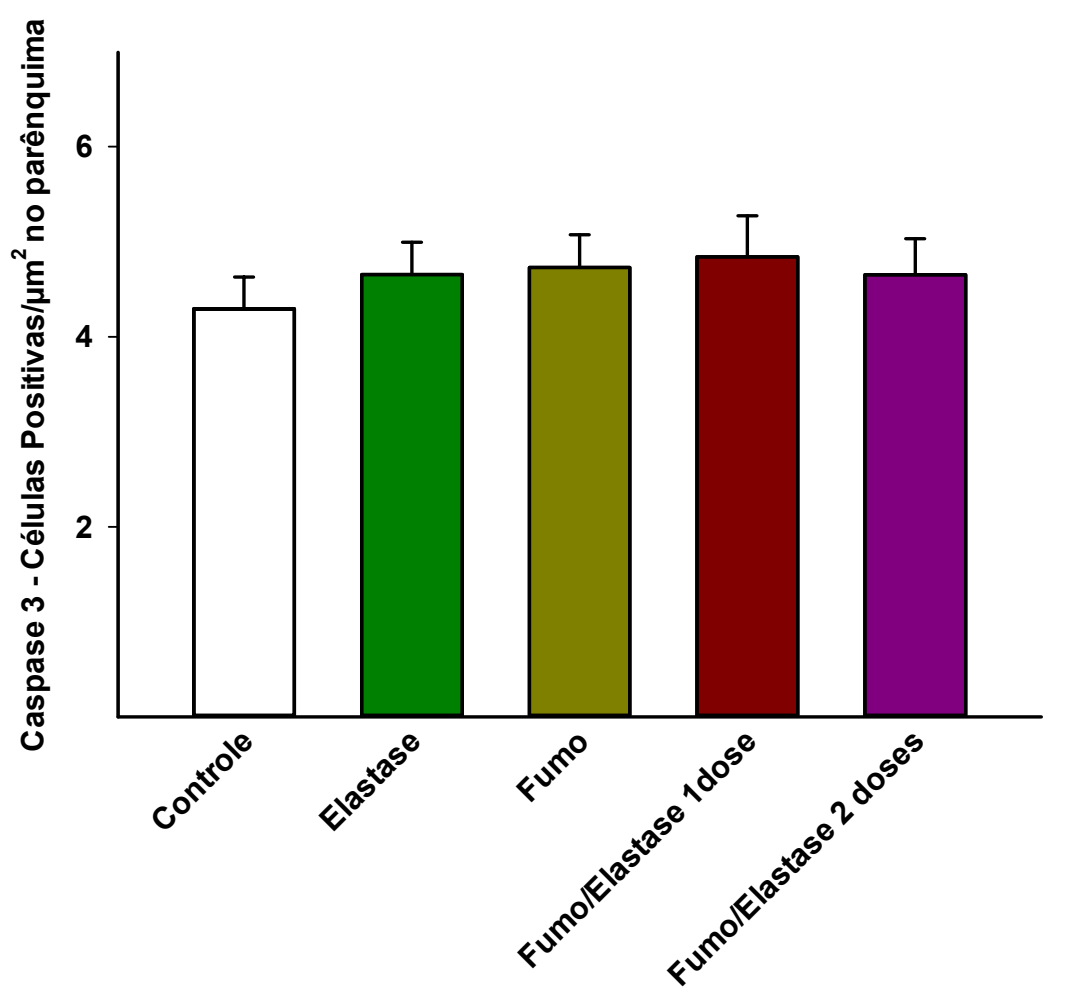

Figura 16: Contagem de células positivas para Caspase 3 no parênquima pulmonar. Os valores estão expressos como média \pm EP. Não houve diferença estatisticamente significativa entre os grupos, $\mathrm{p}=0,872$.

(Controle $n=9$, Elastase $n=9$, Fumo $n=10$, Fumo/Elastase 1 dose $n=10$, Fumo/Elastase 2 doses $n=10$ )

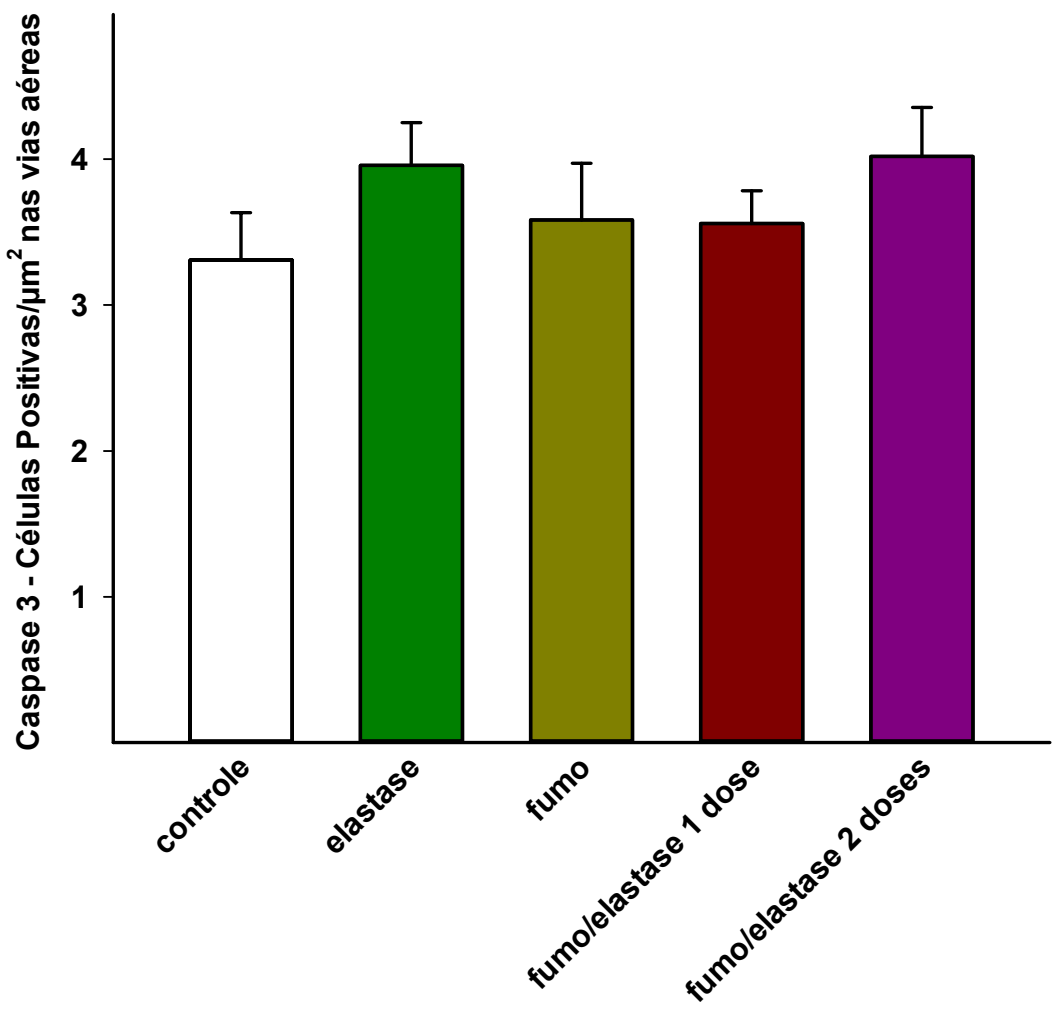

Figura 17: Contagem de células positivas para Caspase 3 nas vias aéreas. Os valores estão expressos como média $\pm E P$. Não houve diferença estatisticamente significativa entre os grupos, $p=0,472$.

(Controle $n=9$, Elastase $n=9$, Fumo $n=10$, Fumo/Elastase 1 dose $n=10$, Fumo/Elastase 2 doses $n=10$ ) 


\subsection{Proporção de fibras de colágeno no parênquima pulmonar}

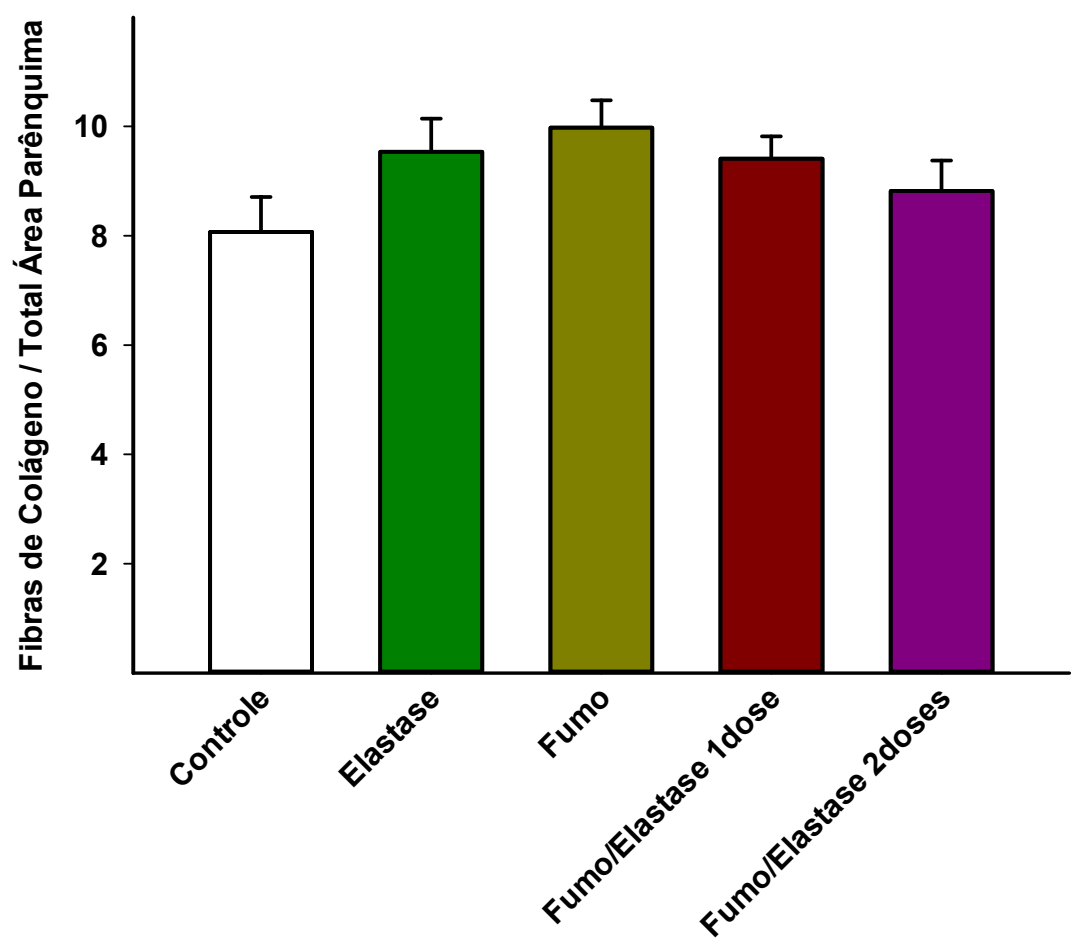

Figura 18: Proporção de fibras de colágeno no parênquima pulmonar nos 5 grupos experimentais. Os valores estão expressos como média \pm EP. Não houve diferença estatisticamente significativa entre os grupos, $\mathrm{p}=0,158$.

(Controle $n=9$, Elastase $n=9$, Fumo $n=10$, Fumo/Elastase 1 dose $n=10$, Fumo/Elastase 2 doses $n=10$ ) 


\subsection{Proporção de fibras elásticas no parênquima pulmonar}

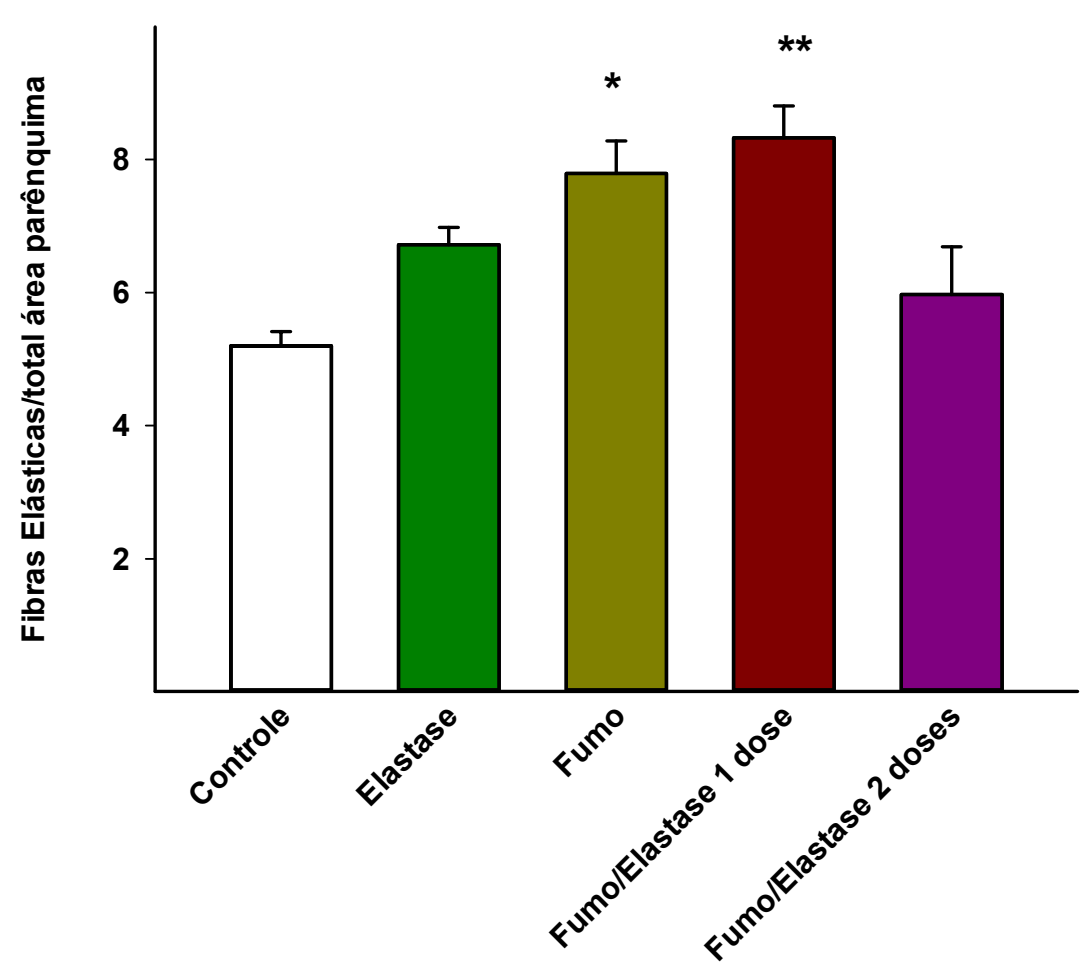

Figura 19: Proporção de fibras elásticas no parênquima pulmonar remanescente dos 5 grupos experimentais.

Os valores estão representados como média \pm EP. Sendo * $p=0,004$, comparado ao grupo Controle $e^{* \star} p<0,05$ comparado aos grupos controle e Fumo/Elastase 2 doses.

(Controle $n=9$, Elastase $n=9$, Fumo $n=10$, Fumo/Elastase 1 dose $n=10$, Fumo/Elastase 2 doses $n=10$ ) 


\section{DISCUSSÃO}

No atual estudo, demonstramos que a associação de instilação de PPE e exposição à fumaça de cigarro foram suficientes para o desenvolvimento de enfisema pulmonar em camundongos, caracterizado pelo aumento dos espaços aéreos após apenas 2 meses de exposição à fumaça de cigarro, tanto para o grupo que utilizamos somente uma dose de PPE quanto para aquele em que utilizamos 2 doses desta elastase. Embora, não tenhamos observado diferença quanto ao grau de lesão tecidual entre os grupos que receberam diferentes doses de elastase, as análises funcionais e morfológicas apresentaram diferenças importantes.

Apesar de haver aumento de LM nos dois grupos expostos à fumaça de cigarro em associação com instilação de PPE, este aumento ainda é inferior ao observado nos estudos que utilizam somente instilação de PPE em doses maiores (Anciães et al., 2011; Lopes et al., 2013; Ito et al., 2005), entretanto apresenta valores similares aos estudos que utilizam somente exposição ao tabaco por tempos bastante prolongados. A maioria dos estudos experimentais que utilizam somente a exposição à fumaça de cigarro demonstra que, apesar de um tempo médio de exposição considerado longo (por volta de 6 meses), a lesão tecidual decorrente ainda é considerada de grau leve, o que possivelmente corresponderia a um paciente com DPOC em estágio inicial, seguindo os critérios do GOLD (Wright et al., 1999).

Em trabalho prévio desenvolvido em nosso laboratório observamos que após 6 meses de exposição com o mesmo equipamento e frequência de exposições semelhantes ao utilizado neste presente estudo (5 dias por 
semana, 1 vez ao dia, $30 \mathrm{~min}$ ) houve aumento de células inflamatórias, com predominância de macrófagos, diminuição de elastância e resistência teciduais, aumento de LM e de deposição de fibras colágenas (Toledo et al., 2012). Ao compararmos os valores de LM deste estudo prévio com o atual, observamos que enquanto o valor da média de LM no grupo Fumo 6 meses foi de 57,357 (DP $\pm 6,076$ ), o valor médio de LM do grupo Fumo/Elastase 1 dose foi de 51,581 ( $\mathrm{DP} \pm 4,246)$ e Fumo/Elastase 2 Doses foi de 53,116 (DP $\pm 1,190)$, não havendo diferença estatística quando comparados. Os valores médios de LM dos grupos Controle 6 meses e Controle 2 meses não apresentam diferença estatisticamente significativa.

Em relação ao remodelamento das fibras, não observamos aumento de deposição de colágeno em nenhum dos grupos estudados, entretanto encontramos aumento de deposição de fibras elásticas no grupo Fumo/Elastase 1 dose comparado ao restante dos grupos. Na maior parte dos estudos desenvolvidos por nosso grupo (Lopes et al., 2008; Anciães et al., 2011; Toledo et al., 2012) e descritos na literatura (Ito et al., 2005; Vlahovic et al., 1999), é relatado um aumento do depósito destas fibras, o qual ocorre devido ao processo de reparo tecidual. Entretanto existem diferenças quanto ao padrão de deposição dependendo do modelo experimental escolhido e do tempo analisado.

Em estudo recente, demonstramos diferenças nos padrões de deposição dos subtipos de colágeno (Tipo I e Tipo III) e dos subcomponentes das fibras elásticas (fibrilina e elastina) quando comparamos os modelos de exposição à fumaça de cigarro e instilação de PPE. A instilação de PPE promove aumento da deposição de elastina e de colágeno tipo III após 28 dias, enquanto que 
após 6 meses da exposição à fumaça de cigarro resulta em aumento de deposição de fibrilina e de colágeno tipo III, sendo que o aumento deste subtipo de colágeno atingiu valores mais altos que os encontrados para o modelo que utilizou PPE. Tais características revelam que o modelo de exposição à fumaça de cigarro apresenta um padrão de remodelamento mais imaturo comparado ao que utiliza PPE e isto se deve ao fato de, a exposição à fumaça de cigarro por vários meses todos os dias, promover uma inflamação crônica (Lopes et al., 2013).

É possível que em nosso estudo, o tempo de exposição à fumaça de cigarro e as doses de PPE não tenham sido suficientes para proporcionar o aumento de depósito de fibras de colágeno. Quanto às fibras elásticas, o aumento da proporção destas foi detectado no grupo exposto à fumaça de cigarro que recebeu uma dose somente de PPE, o grupo que recebeu a mesma exposição ao fumo, mas com mais uma dose de PPE, não observamos o mesmo comportamento. Possivelmente isto tenha ocorrido devido às diferentes doses de PPE utilizadas; talvez nos animais que receberam duas instilações da solução de elastase, o parênquima leve mais tempo para demonstrar aumento de deposição de fibras.

A medida da função pulmonar, embora não seja considerada a mais sensível para detecção de enfisema, especialmente em roedores, devido às dificuldades técnicas, é considerada importante para a caracterização da presença da doença em modelos experimentais, uma vez que em pacientes, o diagnóstico da doença é feito através de teste de função pulmonar para determinação do volume expiratório forçado após 1 segundo (VEF1) (Gold, 2013). 
Entretanto, em nosso estudo, não detectamos alteração em nenhum dos parâmetros avaliados através da avaliação da mecânica respiratória. Nem a exposição ao fumo, nem a instilação somente de PPE e nem mesmo a associação de ambas promoveu a diminuição de Htis, principal parâmetro utilizado em estudos experimentais de enfisema pulmonar. É possível que o grau de lesão tecidual encontrado no modelo experimental que utilizamos não tenha sido suficiente para promover alteração da função pulmonar.

Anciães et al. (2011) desenvolveram um estudo temporal em camundongos, no qual faziam avaliações histológicas e funcionais para detecção da presença de enfisema após instilação intranasal de Papaína (6000 Ul/mg- Valdequímica Produtos Químicos - Brasil) diluída em solução fisiológica ( $\mathrm{NaCl} 0,9 \%$ ) com uma concentração de $20 \mathrm{mg} / \mathrm{mL}$. Observaram que embora houvesse, ao longo do desenvolvimento da doença, alterações funcionais e morfológicas, estes últimos parâmetros foram mais sensíveis para detectar a presença do enfisema. Isto se deve ao fato de não terem detectado as alterações funcionais em todos os tempos nos quais foi demonstrado aumento de LM, comprovando a presença de enfisema.

Acreditamos que os resultados obtidos com a utilização deste modelo experimental que associa exposição à fumaça de cigarro com instilação prévia de elastase reforçam ainda mais a hipótese do desequilíbrio protease/antiprotease para o desenvolvimento do enfisema pulmonar. Segundo esta teoria, as células inflamatórias que migram para o sistema respiratório em resposta a fatores exógenos como fumaça de cigarro e/ou poluentes, são responsáveis pela liberação de proteases, as quais estão envolvidas na destruição das fibras 
constituintes do parênquima pulmonar e consequente perda de elasticidade pulmonar (Suki et al., 2003; Saetta et al., 2003).

Os primeiros modelos experimentais descritos na literatura utilizavam a instilação de papaína para indução do enfisema pulmonar (Wright et al.,2008). Somente em 1990, Wright e colaboradores propuseram a utilização de um modelo experimental com exposição à fumaça de cigarro em cobaias (porquinhos-da-Índia). Os animais foram expostos a 10 cigarros por dia, 5 dias por semana, durante 1, 3, 6 e 12 meses. Após 3 meses observaram presença de um enfisema progressivo caracterizado por aumento de LM e redução de VEF1 demonstrando alterações funcionais, com migração de neutrófilos, macrófagos e linfócitos CD4+ para o trato pulmonar. No entanto, quando houve a interrupção da exposição, embora não tenha havido reversão do processo inflamatório, não se observou evolução deste (Wright et al., 1990; Meshi et al., 2002; Wright et al., 2001).

As cobaias são mais susceptíveis ao desenvolvimento do enfisema quando expostas ao fumo quando comparadas aos camundongos e ratos, além de apresentar maior facilidade para aquisição dos dados funcionais devido ao maior tamanho. No entanto, deixou-se de utilizar esta espécie nestes modelos devido ao alto custo e falta de ferramentas como anticorpos específicos para o avanço no entendimento dos mecanismos envolvidos no desenvolvimento da doença (Wright et al., 2008).

As vantagens na utilização dos camundongos compreendem desde o menor custo e variedade de reagentes e anticorpos para estudos em biologia molecular e imunohistoquímica até a oportunidade de utilizar diferentes linhagens as quais podem sofrer manipulações genéticas para aumento da 
susceptibilidade ao desenvolvimento do enfisema (Guerassimov et al., 2005; March et al., 2006; Takubo et al., 2002).

O modelo de exposição à fumaça de cigarro é reconhecido por ser o que melhor mimetiza a fisiopatologia do enfisema observado em humanos, uma vez que se observa primeiro a instalação de um processo inflamatório para depois ocorrer a instalação da lesão tecidual. No entanto, o tempo prolongado de exposição requerido para a indução do enfisema e a presença de uma lesão do parênquima considerada leve comparada ao modelo de elastase (PPE) tem sido apontado como um problema para a utilização deste modelo (Lopes et al., 2013).

A utilização da instilação de PPE associada à exposição à fumaça de cigarro, possivelmente tornou os animais mais susceptíveis ao desenvolvimento do enfisema pulmonar.

Para melhor entendimento dos mecanismos envolvidos na patogênese do enfisema com a utilização deste modelo, avaliamos expressão de células positivas para macrófagos, MMP-12, caspase-3 e gp91 ${ }^{\text {Phox }}$, tanto nas regiões próximas às vias aéreas quanto nas regiões mais distais do parênquima. É importante ressaltar que o alargamento dos espaços alveolares, em nosso estudo, foi observado somente nas regiões mais distais do parênquima, caracterizando um enfisema do tipo panacinar. Entretanto, optamos por avaliar as marcações específicas descritas acima, tanto em vias aéreas quanto em porções mais distais para verificar se independentemente da lesão tecidual encontrada, verificaríamos diferenças nos padrões inflamatórios nas duas regiões analisadas. 
Para nossa surpresa, apesar de termos encontrado aumento da densidade de macrófagos nas vias aéreas tanto para o grupo Fumo/Elastase 1 dose quanto para o Fumo/Elastase 2 doses, comparados aos outros grupos, encontramos aumento de células positivas para MMP-12 somente na região do parênquima para o grupo Fumo/Elastase 2 doses, dado este que corrobora com o achado de aumento de densidade de macrófagos no parênquima somente no grupo Fumo/Elastase 2 doses.

Já está demonstrado em modelos de indução de enfisema com utilização de proteases que há migração de macrófagos para regiões que sofrem lesão e que os fragmentos de elastina exercem uma atividade quimiotática para os monócitos (Houghton at al., 2006). Em pacientes enfisematosos, estas células encontram-se em paredes alveolares destruídas (Barnes, 2003).

A MMP-12 é liberada predominantemente por macrófagos e é considerada uma das principais enzimas envolvida na destruição de elastina e consequente desenvolvimento do enfisema em roedores (Chaudhuri et al., 2012; Churg et al., 2012). Camundongos manipulados geneticamente, deficientes em MMP-12, quando expostos a um protocolo de exposição à fumaça de cigarro, não apresentam aumento do número de macrófagos e também não desenvolvem enfisema após o período de exposição (Hogg et al., 2002; Hautamaki et al., 1997).

Já, as análises referentes à expressão de gp91Phox, demonstram que somente a exposição à fumaça de cigarro promoveu aumento do mecanismo de estresse oxidativo tanto nas regiões próximas às vias aéreas quanto nas regiões mais distais do parênquima e que houve diferenças nas respostas 
encontradas nos diferentes compartimentos entre os grupos que foram expostos à fumaça de cigarro, mas que receberam diferentes doses de elastase. Observamos aumento da expressão de gp91 ${ }^{\text {Phox }}$ em vias aéreas e parênquima dos indivíduos que pertenciam ao grupo Fumo/Elastase 1 dose, enquanto que os do grupo Fumo/Elastase 2 doses apresentaram aumento da expressão deste marcador somente no parênquima.

Com o processo inflamatório e migração de macrófagos ocorre uma maior liberação de espécies reativas de oxigênio (EROs) e nitrogênio que levam ao estresse oxidativo, geralmente por haver um desequilíbrio entre oxidantes e antioxidantes. Em fumantes, os macrófagos alveolares liberam mais EROs que em não fumantes e a capacidade antioxidante do plasma está reduzida (Wright et al., 1999). O aumento da liberação de EROs traz consequentemente o aumento da oxidação de antiproteases como a a1-AT, podendo assim ativar as MMPs, aumentando a proteólise (Barnes, 2003).

Desta forma acreditamos que a lesão tecidual encontrada no grupo Fumo/Elastase 2 doses seja consequência tanto do aumento da migração de macrófagos e da liberação de MMP-12 quanto da presença de estresse oxidativo. Enquanto que no grupo Fumo/Elastase 1 dose a destruição tecidual mais distal pode ser explicada somente pelo aumento da expressão de gp91 ${ }^{\text {Phox }}$, indicando aumento do mecanismo de estresse oxidativo.

O modelo experimental proposto por nós reforça a importância dos mecanismos de inflamação, com a participação de macrófagos e da MMP-12, e do mecanismo do estresse oxidativo na patogênese do enfisema pulmonar. As diferenças encontradas nos grupos que foram expostos à fumaça de cigarro e que receberam diferentes doses de PPE chamam a atenção mais uma vez 
para a importância de se entender bem os diferentes tipos de modelos experimentais propostos na literatura para a escolha destes para um determinado estudo.

É importante ressaltar que a instilação de elastase, em dose menor do que a utilizada na literatura, não foi suficiente para promover tanto o processo inflamatório quanto destruição tecidual, mas somente para promover um desequilíbrio entre proteases e as anti-proteases endógenas.

Apesar do tempo reduzido de exposição à fumaça de cigarro, o grau de lesão do parênquima obtido neste estudo atual, através da avaliação de LM, foi semelhante aos resultados apresentados na literatura após tempos prolongados de exposição. Entretanto, ainda assim, não é um modelo de exposição única e somente à fumaça de cigarro para indução do enfisema pulmonar. 


\section{CONCLUSÕES}

A utilização de PPE em associação à exposição à fumaça de cigarro resultou em lesão do parênquima com aumento de LM, em um tempo menor do que os descritos em outros estudos que utilizam somente exposição ao fumo.

Além disto, a lesão encontrada independentemente da dose de PPE utilizada foi semelhante as descritas na literatura em estudos que utilizam tempos prolongados de exposição à fumaça de cigarro

A instilação de elastase pancreática de porco antes do início da exposição à fumaça de cigarro aumentou a susceptibilidade ao desenvolvimento do enfisema, provavelmente por ter aumentado o desequilíbrio protease/anti-protease, comprovado pelo aumento de macrófagos em vias aéreas e parênquima, de células positivas para MMP-12 no parênquima e pela presença de estresse oxidativo observado pelo aumento de células positivas para gp91 ${ }^{\text {Phox }}$ no parênquima, nos animais que receberam 2 instilações de PPE. Enquanto que uma instilação apenas, apesar de ter promovido aumento de macrófagos nas vias aéreas, não promoveu aumento de MMP-12, mas aumento da expressão de gp91 ${ }^{\text {Phox }}$ em vias aéreas e parênquima. 


\section{REFERÊNCIAS}

1. Anciães AM, Olivo CR, Prado CM, Kagohara K, Pinto TS, Moriya HT, Mauad T, Martins MA, LOPES FDTQS. Respiratory mechanics do not always mirror pulmonary histological changes in emphysema. CLINICS. 2011;66(10):1797-1803.

2. Aoshiba K, Yokohori N, Nagai A. Alveolar wall apoptosis causes lung destruction and emphysematous changes. Am J Respir Cell Mol Biol. $2003 ; 28: 555-62$.

3. AccessKeatings VM, Collins PD, Scott DM, Barnes PJ. Differences in interleukin-8 and tumor necrosis factor in induced sputum from patients with chronic obstructive pulmonary disease or asthma. Am. J. Resp. Crit. Care Med.1996;153:530-34.

4. Babior BM. NADPH Oxidase: An Update. Blood. 1999;93(5).

5. Barnes PJ. New concepts in chronic obstructive pulmonary disease. Annu Rev Med. 2003; 54:113-29.

6. Biselli PC, Lopes FDTQS, Moriya HT, Rivero DHRF, Toledo AC, Saldiva PHN, Mauad T, Martins MA. Short-term exposure of mice to cigarette smoke and/or residual oil fly ash produces proximal airspace enlargements and airway epithelium remodeling. Braz J Med Biol Res. 2011;44(55): 460-68.

7. Cavarra E, Bartalesi B, Lucattelli M, Fineschi S, Lunghi B, Gambelli F, Ortiz LA, Martorana PA, Lungarella G. Effects of cigarette smoke in mice with diferente levels of $\alpha 1$-proteinase inhibitor and sensitivity to oxidants. Am J Respir Crit Care Med. 2001;164:886-890. 
8. Cave AC, Brewer AC, Narayanapanicker A, Ray R, Grieve DJ, Walker S, Shah AM. NADPH oxidases in cardiovascular health and disease. Antioxid Redox Signal. 2006;8(5-6):691-728.

9. Chaudhuri R, McSharry C, Brady J, Donnelly I, Grierson C, McGuinness S, Jolly L, Weir CJ, Messow MC, Spears M, Miele G, Nocka K, Crowther D, Thompson J, Brannigan M, Lafferty J, Sproule M, MacNee W, Connell M, Murchison JT, Shepherd MC, Feuerstein G, Miller DK, Thomson NC. Sputum matrix metalloproteinase-12 in patients with chronic obstructive pulmonary disease and asthma: Relationship to disease severity. $J$ Allergy Clin Immunol. 2012;129(3):655-663.

10. Churg A, Wang RD, Tai $\mathrm{H}$. Macrophage metalloelastase mediates acute cigarette smoke-induced inflammation via tumor necrosis factor- $\alpha$ release. Am J Respir Crit Care Med. 2003;167:1083-1089.

11. Churg A, Wang R, Wang X, Onnerwik P, Tin K, Wright JL. Effect of an MMP-9/MMP-12 inhibitor on smoke-induced emphysema and airway remodeling in guinea pigs. Thorax. 2007;62:706-713.

12. Churg A, Cosio M, Wright JL. Mechanisms of cigarette smoke-induced COPD: insights from animal models. Am J Physiol Lung Mol Physiol. 2008;294:L612-L631.

13. Churg A, Zhou S, Wright JL. Matrix metalloproteinases in lung health and disease. Eur Respir J. 2012;39:197-209.

14.Dekhuijzen PNR, Aben KHH, Dekker I. Increased exhalation of hydrogen peroxide in patients with stable and unstable chronic obstructive pulmonary disease. Am. J. Resp. Crit. Care Med.1996;154:813-16. 
15.El-Benna J, Dang PM, Gougerot-Pocidalo MA, Elbim C. Phagocyte NADPH oxidase: a multicomponent enzyme essential for host defenses. Arch Immunol Ther Exp. 2005;53(3):199-206.

16.Fabbri L, Pauwels RA, Hurd SS, GOLD Scientific Committee. Global strategy for the diagnosis, management, and prevention of chronic obstructive pulmonary disease: GOLD Executive Summary updated 2003. COPD. 2003;1:105-41.

17.Finkelstein R, Fraser RS, Ghezzo H, et al. Alveolar inflammation and its relation to emphysema in smokers. Am. J. Resp. Crit. Care Med. 1995; 152:1666-72.

18.Global Strategy for the Diagnosis, Management and Prevention of COPD, Global Initiative for Chronic Obstructive Lung Disease (GOLD) 2013. Available from: http://www.goldcopd.org.

19. Groemping $Y$ and Rittinger K. Activation and assembly of the NADPH oxidase: a structural perspective. Biochem J. 2005;386:401-416.

20. Grote K, Ortmann M, Salguero G, Doerries C, Landmesser U, Luchtefeld M, Brandes RP, Gwinner W, Tschernig T, Brabant EG, Klos A, Schaefer A, Drexler H, Schieffer B. Critical role for p47phox in renin-angiotensin system activation and blood pressure regulation. Cardiovasc Res. 2006;71(3):596-605.

21. Guerassimov A, Hoshino M, Takubo Y, Turcotte A, Yamamoto M, Ghezzo H, Triantafillopoulos A, Whittaker K, Hoidal JR, Cosio MG. The development of emphysema in cigarette smoke-exposed mice is strain dependent. Am. J. Resp. Crit. Care Med. 2005;170:974-980. 
22. Halbert RJ, Natoli JL, Gano A, Badamqarav E, Buist AS, and Mannino DM. Global burden of COPD: systematic review and meta-analysis. Eur Respir J. 2006;28:523-532.

23.Hantos, Z., Daróczy, B., Suki, B., Nagy, S., Fredberg, J.J., 1992. Input impedance and peripheral inhomogeneity of dog lungs. J. Appl. Physiol. 72(1), 168-78.

24. Harber P, Tashkin DP, Simmons M, Crawford L, Hnizdo E, Connett J, and Lung Health Study Group. Effect of occupational exposures on decline of lung function in early chronic obstructive pulmonary disease. Am J Respir Crit Care Med. 2007;176:994-1000.

25. Harkema J, Plopper C, Hyde D, St. George J, Wilson D, Dungworth D. Response of macaque bronchiolar epithelium to ambiente concentrations of ozone. Am J Pathol 1993; 143:857-66.

26. Harman D. Aging: a theory based on free radical and radiation chemistry. J Gerontol. 1956;11(3):298-300.

27. Hautamaki RD, Kobayashi DK, Senior RM, Shapiro SD. Requeriment for macrophage elastase for cigarette smoke-induced emphysema in mice. Science. 1997;277:2002-2004.

28. Heck JD, Gaworski CL, Rajendran N, Morrissey RL. Toxicologic evaluation of humectants added to cigarette tobacco: 13-week smoke inhalation study of glycerin and propylene glycol in Fischer 344 rats. Inhal Toxicol. 2002;14: 1135-1152.

29. Hogg JC, Senior RM. Chronic obstructive pulmonary disease c2: Pathology and biochemistry of emphysema. Thorax. 2002;57:830-834. 
30. Houghton AM, Quintero PA, Perkins DL, Kobayashi DK, Kelley DG, Marconcini LA, Mecham RP, Senior RM, Shapiro SD. Elastin fragments drive disease progression in a murine model of emphysema. J Clin Invest. 2006;116:753-9.

31.Imai K, Mercer BA, Schulman LL, Sonett JR, D'Armiento JM. Correlation of lung surface area to apoptosis and proliferation in human emphysema. Eur Respir J. 2005; 25:250-8.

32. Ito S, Ingenito EP, Brewer KK, Lauren DB, Harikrishnan P, Lutchen KR, Suki B. Mechanics, nonlinearity and failure strength of lung tissue in a mouse of emphysema: possible role of collagen remodeling. $\mathrm{J}$ Appl Physiol. 2005;98:503-11.

33. Janoff A. Elastases and emphysema. Am Rev Respir Dis. 1985;132:41733.

34.Janoff A, White R, Carp H, Harel S, Dearing R, Lee D. Lung injury induced by leukocytic proteases. Am J Pathol. 1979;97:111-36.

35. Kasahara Y, Tuder RM, Taraseviciene-Stewart L, Le Cras TD, Abman S, Hirth PK, Waltenberger J, Voelkel NF. Inhibition of VEGF receptors causes lung cell apoptosis and emphysema. $\mathrm{J}$ Clin Invest. 2000;106:1311-19.

36. Kassim SY, Fu X, Liles WC, Shapiro SD, Parks WS, Heinecke JW. NADPH oxidase restrains the Matrix Metalloproteinase activity of macrophages. J. Biol. Chem. 2005.

37.Lacoste JY, Bousquet J, Chanez P. Eosinophilic and neutrophilic inflammation in asthma, chronic bronchitis and chronic obstructive pulmonary disease. J. Allergy Clin. Immunol. 1993;92:537-48. 
38. Lieberman J. Elastase collagenase emphysema and alpha-1-antitrypsin deficiency. Chest.1976; 70: 62-7.

39.Lopes FDTQS, Toledo AC, Olivo CR, Prado CM, Leick EA, Medeiros MC, Santos ABG, Garippo A, Martins MA, Mauad T. A comparative study of extracellular matrix remodeling in two murine models of emphysema. Histol Histopathol. 2013;28:269-276.

40. Maeno T, Houghton AM, Quinton PM, Grumelli S, Owen CA, Shapiro SD. CD8+ $T$ cells are required for inflammation and destruction in cigarette smoke-induced emphysema in mice. J Immunol. 2007;178:8090-8096.

41. March TH, Wilder JA, Esparza DC, Cossey PY, Blair LF, Herrera LK, McDonald JD, Campen MJ, Mauderly JL, Seagrave J. Modulators of cigarette smoke-induced pulmonary emphysema in A/J mice. Toxicology. 2006;92:545-559.

42. Margraf LR, Tomashefski JF, Bruce MC, Dahms BB. Morphometric analysis of the lung in bronchopulmonary dysplasia. Am Rev Respir Dis. $1991 ; 143: 391-400$.

43. Martinez FO, Helming L, Gordon S. Alternative activation of macrophages: an immunologic functional perspective. Annu Rev Immunol. 2009;27:451-83.

44.Meshi B, Vitalis TZ, Ionescu D, et al. Emphysematous lung destruction by cigarette smoke. The effects of latent adenoviral infection on the lung inflammatory response. Am J Respir Cell Mol Biol. 2002;26:52-7.

45. Molet S, Belleguic C, Lena $\mathrm{H}$, et al. Increase in macrophage elastase (MMP-12) in lungs from patients whit chronic obstructive pulmonary disease. Inflamm Res. 2005; 54:31-36. 
46. Montuschi P, Collins JV, Ciabattoni G, et al. Exhaled 8-isoprostane as an in vivo biomarker of lung oxidative stress in patients with COPD and healthy smokers. Am. J. Resp. Crit. Care Med. 2000;162:1175-77.

47. Movahedi K, Laoui D, Gysemans C, Baeten M, Stangé G, Van den Bossche J, Mack M, Pipeleers D, In't Veld P, De Baetselier P, Van Ginderachter JA. Different tumor microenvironments contain functionally distinct subsets of macrophages derived from Ly6C(high) monocytes. Cancer Res. 2010;70(14):5728-39.

48. Organização Mundial de Saúde (OMS); WHO Global Infobase: Data for saving $\quad$ lives. $2013 . \quad$ Disponível em http://apps.who.int/infobase/Indicators.aspx?ISO3=bral.

49. Pauwels RA and Rabe KF. Burden and clinical features of chronic obstructive pulmonary disease. Lancet. 2004;364:613-620.

50.Piitulainen E, Erickson S. Decline in FEV1 related to smoking status in individuals with severy alpha1-antitrypsin deficiency (Pi ZZ). Eur Respir J. $1999 ; 13: 247-51$.

51. Quinn MT1, Ammons MC, Deleo FR. The expanding role of NADPH oxidases in health and disease: no longer just agents of death and destruction. Clin Sci (Lond). 2006;111(1):1-20.

52. Rabe KF, Hurd S, Anzueto A, Barnes PJ, Buist SA, Calverley P, Fukuchi Y, Jenkins C, Rodriguez-Roisin R, van Weel C, Zielinski J. Global strategy for the diagnosis, management, and prevention of chronic obstructive pulmonary disease: GOLD executive summary. Am J Respir Crit Care Med. 2007;176:532-55. 
53.Sahebjami H. Effects of postnatal starvation and refeeding on rat lungs during adulthood. Am Rev Respir Dis. 1986;133:769-72.

54.Sahebjami H, MacGee J. Effects of starvation and refeeding on lung biochemistry in rats. Am Rev Respir Dis. 1982;126:483-7.

55.Saetta M., Turato G., Timens W., Jeffery P.K. Pathology of chronic obstructive pulmonary Disease. Eur Respir Mon. 2006;38:159-176.

56. Segura-Valdez L, Pardo A, Gaxiola M, Uhal BD, Becerril C, Selman M. Upregulation of gelatinases $A$ and $B$, collagenases 1 and 2 , and increased parenchymal cell death in COPD. Chest. 2000;117:684-94.

57. Shapiro SD. The macrophage in chronic obstructive pulmonary disease. Am J Respir Crit Care Med. 1999;160:S29-S32.

58. Shapiro SD, Goldstein NM, Houghton AM, Kobayashi DK, Kelley D, and Belaaouaj A. Neutrophil Elastase Contributes to Cigarette SmokeInduced Emphysema in Mice. Am J Pathol. 2003;163(6):2329-2335.

59.Shifren A., Mecham R. P. The Stumbling Block in Lung Repair of Emphysema: Elastic Fiber Assembly. Proc Am Thorac Soc. 2006;3:428433.

60.Stang P, Lydick E, Silberman C, Kempel A, and Keating ET. The prevalence of COPD: using smoking rates to estimate disease frequency in the general population. Chest. 2000;117:354S-359S.

61.Suki B., Lutchen K.R., Ingenito E.P. On the Progressive Nature of Emphysema, Roles of Proteases, Inflammation, and Mechanical Forces. Am J Respir Crit Care Med. 2003;168:516-521.

62. Takubo Y, Guerassimov A, Ghezzo H, Triantafillopoulos A, Bates JHT, Hoidal JR, Cosio MG. a1-antitripsina determines the pattern of 
emphysema and function in tobacco smoke-exposed mice. Parallels with human disease. Am J Respir Crit Care Med. 2002;166:1596-1603.

63. Toledo AC, Magalhães RM, Hizume DC, Vieira RP, Biselli PJC, Moriya HT, Mauad T, Lopes FDTQS, Martins MA. Aerobic exercise attenuates pulmonary injury induced by exposure to cigarette smoke. Eur Respir J. 2012;39(2): 254-264.

64. Valko M, Leibfritzb D, Moncola J, Croninc MTD, Mazura M, Telserd J. Free radicals and antioxidants in normal physiological functions and human disease. Int J Biochem Cell Biol. 2007;39(1):44-84.

65. Vernooy JHJ, Dentener MA, van Suylen RJ, Buurman WA, Wouters EFM. Long-term intratracheal lipopolysaccharide exposure in mice results in chronic lung inflammation and persistent pathology. Am J Respir Cell Mol Biol. 2002; 26:152-159.

66. Vlahovic G, Russel ML, Mercer RR, Crapo JD. Cellular and connective tissue changes in alveolar septal walls in emphysema. Am J Respir Crit Care Med. 1999;160:2086-92.

67. Wright JL, Cosio M, Churg A. Animal models of chronic obstructive pulmonary disease. Am J Physiol Lung Cell Mol Physiol. 2008;295:L1L15.

68. Wright JL, Tai H, Churg A. Vasoactive mediators and pulmonary hypertension after cigarette smoke exposure in the guinea pig. J Appl Physiol. 2006;100:672-678.

69. Wright JL. The importance of ultramicroscopic emphysema in cigarette smoke-induced lung disease. Lung. 2001;179:71-81. 
70.Wright JL, Churg A. Cigarette smoke causes physiologic and morphologic changes of emphysema in the guinea pig. Am Rev Respir Dis. 1999; 142:1422-1428.

71. Wright JL, Sun JP. The effect of smoking cessation on pulmonary and cardiovascular function and structure. J Appl Physiol. 1994;76:2163-68.

72. Yokohori N, Aoshiba K, Nagai A. Increased levels of cell death and proliferation in alveolar wall cells in patients with pulmonary emphysema. Chest. 2004;125:626-32. 